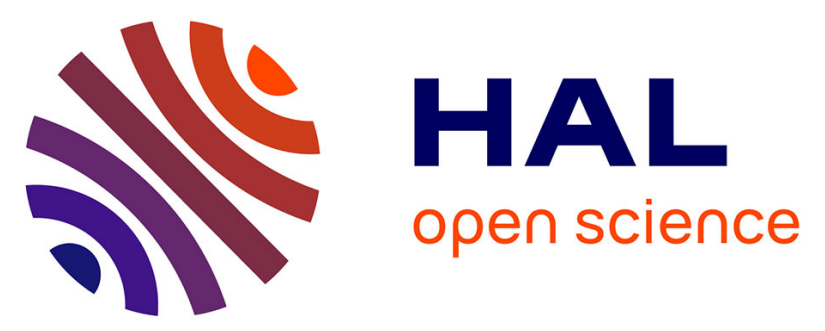

\title{
Microbial absorption and backscattering coefficients from in situ and POLDER satellite data during an El Niño-Southern Oscillation cold phase in the equatorial Pacific $\left(180^{\circ}\right)$
}

Cécile Dupouy, Hubert Loisel, Jacques Neveux, Susan L. Brown, Cyril Moulin, Jean Blanchot, Aubert Le Bouteiller, Michael R. Landry

\section{To cite this version:}

Cécile Dupouy, Hubert Loisel, Jacques Neveux, Susan L. Brown, Cyril Moulin, et al.. Microbial absorption and backscattering coefficients from in situ and POLDER satellite data during an El NiñoSouthern Oscillation cold phase in the equatorial Pacific $\left(180^{\circ}\right)$. Journal of Geophysical Research, 2003, 108 (C12), 10.1029/2001jc001298 . hal-03259349

\author{
HAL Id: hal-03259349 \\ https://hal.science/hal-03259349
}

Submitted on 14 Jun 2021

HAL is a multi-disciplinary open access archive for the deposit and dissemination of scientific research documents, whether they are published or not. The documents may come from teaching and research institutions in France or abroad, or from public or private research centers.
L'archive ouverte pluridisciplinaire $\mathbf{H A L}$, est destinée au dépôt et à la diffusion de documents scientifiques de niveau recherche, publiés ou non, émanant des établissements d'enseignement et de recherche français ou étrangers, des laboratoires publics ou privés. 


\title{
Microbial absorption and backscattering coefficients from in situ and POLDER satellite data during an EI Niño-Southern Oscillation cold phase in the equatorial Pacific $\left(\mathbf{1 8 0}^{\circ}\right)$
}

\author{
Cécile Dupouy, ${ }^{1,2}$ Hubert Loisel,,${ }^{3,4}$ Jacques Neveux, ${ }^{5,2}$ Susan L. Brown, ${ }^{6}$ Cyril Moulin, ${ }^{7}$ \\ Jean Blanchot, ${ }^{8}$ Aubert Le Bouteiller, ${ }^{9}$ and Michael R. Landry ${ }^{6}$ \\ Received 9 January 2002; revised 5 March 2003; accepted 25 June 2003; published 4 December 2003.
}

[1] Contributions of different microbial groups to absorption, backscattering, and marine reflectance $\left(a(\lambda), b_{\mathrm{b}}(\lambda)\right.$ and $R(\lambda)$, respectively) were quantified during an El NiñoSouthern Oscillation cold phase in the equatorial Pacific during the Etude du Broutage en Zone Equatoriale cruise on board the $\mathrm{R} / \mathrm{V}$ L'Atalante. In situ data were collected at every degree of latitude from $8^{\circ} \mathrm{S}$ to $8^{\circ} \mathrm{N}, 180^{\circ}$ (26 October to 13 November 1996), and satellite reflectances were available from POLDER-ADEOS for the 1-10 November 1996 decade. Bulk absorption and backscattering coefficients were estimated at $440 \mathrm{~nm}$ for the major microbial groups enumerated in the upper surface layer (heterotrophic bacteria,

Prochlorococcus, Synechococcus, and $<20-\mu \mathrm{m}$ eukaryotic algae). Total absorption and backscattering coefficients were retrieved from space by a new inverse method. The observed ecosystem was typical of a well-developed equatorial upwelling, with maximal values of $0.4 \mathrm{mg} \mathrm{m}^{-3}$ for Tchl $a, 0.026 \mathrm{~m}^{-1}$ for $a_{\mathrm{p}}(440), 0.023 \mathrm{~m}^{-1}$ for $a_{\mathrm{phy}}(440)$, and a low in situ $a_{\mathrm{det}}\left(<14 \%\right.$ of $\left.a_{\mathrm{p}}\right)$. Prochlorococcus and nanoeukaryotic algae $(3.4-\mu \mathrm{m}$ mean diameter) were the dominant absorbers $(97 \%)$, contributing about equally to $a_{\text {phy. The }}$. The retrieved total absorption coefficient, $a_{\text {sat }}(440)$, from POLDER (maximum of $0.03 \mathrm{~m}^{-1}$ ) was higher than $a_{\mathrm{p}}(440)$, as it included absorption by CDOM (estimated to be $15 \%$ of $a_{\mathrm{p}}(440)+a_{\mathrm{w}}(440)$, where $a_{\mathrm{w}}=$ absorption by pure water). Heterotrophic bacteria were the dominant contributors $(73 \%)$ to total simulated microbial backscattering, $b_{\text {bmic }}$ (maximum $=$ $\left.3.7 \times 10^{-4} \mathrm{~m}^{-1}\right)$, but $b_{\text {bmic }}$ was negligible compared to the inverted total backscattering by particles, $b_{\mathrm{bp}}\left(2.7 \times 10^{-3} \mathrm{~m}^{-1}\right)$, indicating that unidentified small nonliving particles contributed most to the satellite signal. INDEX TERMS: 1640 Global Change: Remote sensing; 4855 Oceanography: Biological and Chemical: Plankton; 9355 Information Related to Geographic Region: Pacific Ocean; 4522 Oceanography: Physical: El Niño; 4552 Oceanography: Physical: Ocean optics;

KEYWORDS: ocean color, absorption, backscattering, microbial population, equatorial Pacific, El Niño

Citation: Dupouy, C., H. Loisel, J. Neveux, S. L. Brown, C. Moulin, J. Blanchot, A. Le Bouteiller, and M. R. Landry, Microbial absorption and backscattering coefficients from in situ and POLDER satellite data during an El Niño-Southern Oscillation cold phase in the equatorial Pacific $\left(180^{\circ}\right), J$. Geophys. Res., 108(C12), 8138, doi:10.1029/2001JC001298, 2003.

\footnotetext{
${ }^{1}$ Laboratoire d'Océanographie Dynamique et de Climatologie (CNRSIRD-UPMC), UMR 7617, UPMC, Paris, France.

${ }^{2}$ Also at Institut de Recherche pour le Développement-Nouméa, Nouméa, New Caledonia.

${ }^{3}$ Laboratoire d'Optique Atmosphérique, University of Lille 1, Villeneuve d'Ascq, France.

${ }^{4}$ Now at Université du Littoral Côte d'Opale, MREN-UMR 8013 ELICO-LOCL, Wimereux, France.

${ }^{5}$ Observatoire Océanologique de Banyuls (CNRS-UPMC), Laboratoire Arago (UMR 7621), Banyuls sur Mer, France.

${ }^{6}$ Department of Oceanography, University of Hawaii at Manoa, Honolulu, Hawaii, USA.

${ }^{7}$ Laboratoire des Sciences du Climat et de l'Environnement, CEACNRS, Gif-sur-Yvette, France.

${ }^{8}$ Institut de Recherche pour le Développement-Sainte Clotilde, Sainte Clotilde, La Réunion, France.

${ }^{9}$ Institut de Recherche pour le Développement-Nouméa, Nouméa, New Caledonia.
}

Copyright 2003 by the American Geophysical Union. 0148-0227/03/2001JC001298

\section{Introduction}

[2] Absorption, $a(\lambda)$, and backscattering, $b_{\mathrm{b}}(\lambda)$, coefficients within the upper oceanic layer are the two inherent optical properties (IOPs) that need to be determined in order to model water-leaving radiances $L_{\mathrm{w}}(\lambda)$ at a given wavelength $\lambda$. Knowledge of these coefficients is essential for satellite ocean color data applications, as $b_{\mathrm{b}}(\lambda)$ determines the amplitude of the remote sensed reflectance and $a(\lambda)$ modifies its spectral shape [Gordon and Morel, 1983; Morel, 1988]. Besides water, the three main classes of optically significant constituents of seawater are colored dissolved organic matter (CDOM), living particles (viruses, heterotrophic bacteria, phytoplankton, large heterotrophs), and nonliving particulate suspended matter (detritus and minerals). In case I waters, the inherent optical properties are primarily controlled by particulate and dissolved materials associated with primary productivity of phytoplankton. 
Previous studies have shown that the particulate absorption and scattering coefficients are well related to the total chlorophyll $a$ concentration (Tchl $a$ ), the sum of chlorophyll $a+$ divinyl chlorophyll $a$, defining the bio-optical state of a water body [Bricaud et al., 1995, 1998; Morel, 1987; Loisel and Morel, 1998]. On the basis of empirical relationships and different assumptions, some semianalytical models have also been developed between the backscattering coefficient and Tchl a [Morel, 1988; Gordon et al., 1988; Morel and Maritorena, 2001]. These simplified parameterizations of the optical properties in terms of Tchl $a$ do not adequately account for much of the variability observed in natural waters. Even for case I waters, it is not clear how the particle composition determines the $a(\lambda)$ and $b_{\mathrm{b}}(\lambda)$ coefficients and therefore satellite reflectance $R(\lambda)$. A main goal is to discriminate between the CDOM and living and detrital particles. In particular, determining the phytoplankton component is of prime importance given the potential use of ocean color satellite observations for making global estimates of primary production from space [Morel, 1991; Marra et al., 1999; Stramski et al., 1999; Behrenfield et al., 2001; McClain et al., 2002].

[3] Few studies have attempted to determine the contributions of different particles to the variability of the IOPs in natural environments. Pioneer studies succeeded in partitioning the IOPs into plant and detrital pools and among picoplanktonic groups. They used continuous profiles of beam $c_{\mathrm{p}}$ (attenuation coefficient, $c_{\mathrm{p}}=a_{\mathrm{p}}+b_{\mathrm{p}}$ with $b_{\mathrm{p}}$ the particle scattering) [Chung et al., 1996; DuRand and Olson, 1996; Chung et al., 1998; Claustre et al., 1999], in vivo chlorophyll fluorescence [Claustre et al., 1999], and/or $a(\lambda)$ and $b_{\mathrm{p}}(\lambda)$ [Claustre et al., 2000]. Bulk inherent optical properties were linked to the cell abundances of each microbial group multiplied by their average cellular optical cross sections. Such single-cell optical cross-sectional spectra of absorption and backscattering have been determined on cultures and using Mie theory equations [Bricaud et al., 1988; Morel and Ahn, 1990, 1991; Ahn et al., 1992; Morel et al., 1993; Stramski and Reynolds, 1993; Johnsen et al., 1994; Moore et al., 1995; Stramski and Mobley, 1997; Mobley and Stramski, 1997; Stramski et al., 2001]. Since these published optical properties of cultivated species may not correspond to those of phytoplankton populations in equatorial and tropical waters, it is more accurate to assess them from the characteristics of natural populations [Chung et al., 1996; DuRand and Olson, 1996; Chung et al., 1998; Blanchot et al., 2001; Dusenberry et al., 2001; Finkel, 2001]. In this regard, the combination of flow cytometry and microscopy has proven invaluable for assessing the cellular characteristics from which in vivo absorption and backscattering coefficients of natural microbial populations can be determined.

[4] The goal of our study was to determine the contributions of different microbial populations to bulk absorption and backscattering coefficients in the central equatorial Pacific. Estimates of $a(\lambda)$ and $b_{\mathrm{b}}(\lambda)$ coefficients were made between $8^{\circ} \mathrm{S}-8^{\circ} \mathrm{N}, 180^{\circ}$ during the EBENE cruise transect (26 October to 13 November 1996). Sea surface samples were analyzed by flow cytometry, microscopy and pigment/ absorption measurements to assess the IOPs of natural particles [Le Borgne and Landry, 2003]. The inferences of these IOPs simulations on the interpretation of satellite reflectance were subsequently examined using an inverse model to estimate the $a(\lambda)$ and $b_{\mathrm{b}}(\lambda)$ coefficients from a POLDER image corresponding to the location and time of the cruise. From these data, we present an analysis of the influence of the microbial group composition on the variability of the IOPs and satellite reflectance $R(\lambda)$, which can be applied to the ocean color global imagery, at least for case I tropical waters.

\section{Methods}

\subsection{Data Sampling}

[5] The present study was conducted at the end of the 1995-1996 El Niño-Southern Oscillation (ENSO) equatorial cold phase from $8^{\circ} \mathrm{S}$ to $8^{\circ} \mathrm{N}, 180^{\circ}$, between the 26 October 1996 and the 13 November 1996, during the transect of the Etude du Broutage en Zone Equatoriale (EBENE) cruise [Le Borgne and Landry, 2003]. Water samples were taken at regular depths from 0 to $150 \mathrm{~m}$ with 10-L Niskin bottles attached to a CTD rosette. For particulate absorption $\left(a_{\mathrm{p}}\right)$ measurements, 2.3 to $3 \mathrm{~L}$ of seawater were filtered through $25-\mathrm{mm}$ Whatman $\mathrm{GF} / \mathrm{F}$ (vacuum $<75 \mathrm{~mm} \mathrm{Hg}$ ). These filters were kept frozen at $-20^{\circ} \mathrm{C}$ for three months before analysis in the laboratory. For pigment measurements, $500-\mathrm{mL}$ water samples were filtered onto 47-mm Whatman GF/F filters. Additional samples were taken from the same Niskin bottles for shipboard (live) and laboratory-based (paraformaldehydepreserved) flow cytometric (FCM) analyses of the picoplankton and for microscopic $(50-250 \mathrm{~mL})$ assessments of the abundances and carbon biomass of eukaryotic phytoplankton.

\subsubsection{Absorption and Pigment Measurements}

[6] Spectral optical densities of particles concentrated on filters were recorded at 1-nm intervals between 320 and $800 \mathrm{~nm}$ using a Beckman DU-26 dual-beam spectrophotometer [Dupouy et al., 1997]. The absorption of detritus is determined following the procedure of total particulate absorption after chl was extracted with hot methanol [Kishino et al., 1985]. New GF/F filters soaked in filtered seawater were run as blanks. Absorption coefficients were calculated from optical densities by the quantitative filter pad technique, using coefficients determined by Mitchell [1990]. Concentrations of chlorophylls were assessed on shipboard by the spectrofluorometric method of Neveux and Lantoine [1993] with some data acquisition modifications [Neveux et al., 2003].

\subsubsection{Cell Abundances and Characteristics}

[7] Cell counts, cellular fluorescence and forward angle light scattering (FALS) of Prochlorococcus (Pro), Synechococcus (Syn) spp. and picoeukaryotes were determined on fresh samples using a FACScan flow cytometer. Flow cytometry samples of $0.1 \mathrm{~mL}$ were analyzed on shipboard within $2 \mathrm{~h}$ of collection according to the protocol of Blanchot et al. [2001]. DNA-stained heterotrophic bacteria were enumerated from preserved, frozen samples $(1 \mathrm{~mL})$ analyzed by flow cytometry with a Coulter EPICS 753 [Brown et al., 2003]. In this study, picoeukaryotic $(<2-\mu \mathrm{m})$ and nanoeukaryotic $(2-20 \mu \mathrm{m})$ algae were enumerated using a combination of flow cytometry and image-enhanced epifluorescent microscopy of shipboard prepared slides $(50-250 \mathrm{~mL}$ samples) [Brown et al., 2003]. The total abundance of eukaryotic 
phytoplankton was determined by flow cytometric counts of all cells with red (chlorophyll) fluorescence that did not conform to either Pro or Syn fluorescence and scattering properties. Cells $>2-\mu \mathrm{m}$ in length were counted and sized by image-enhanced epifluorescence microscopy, and their biovolumes were estimated using appropriate geometric shapes. The picoeukaryotes $(<2-\mu \mathrm{m}$ in length) were determined as the difference between the total FCM abundance of eukaryotic cells and microscopic estimates of the $>2-\mu \mathrm{m}$. In a system like the equatorial system, there are so few "large $(>8-\mu \mathrm{m})$ " cells $(<50$ per $\mathrm{mL})$ that the difference in volumes examined for total eucaryotes $(0.1 \mathrm{~mL})$ and larger cells $(250 \mathrm{~mL})$ would not significantly affect their enumeration [Brown et al., 2002]. The mean size of picoeukaryotic cells was assumed to be $\sim 1.5 \mu \mathrm{m}$. Cell volume to carbon conversions for picoeukaryotes (Peuk) and nanoeukaryotes (Neuk) were based on modified Strathmann [1967] equations for nondiatom and diatom groups [Eppley et al., 1970] as by Brown et al. [2003].

\subsection{Parameterization and Calculations}

\subsubsection{Total Absorption and Backscattering Coefficients}

[8] Total absorption, $a_{\text {tot }}(\lambda)$, and backscattering, $b_{\text {btot }}(\lambda)$, coefficients can be expressed as

$$
a_{\mathrm{tot}}(\lambda)=a_{\mathrm{w}}(\lambda)+a_{\mathrm{p}}(\lambda)+a_{\mathrm{CDOM}}(\lambda)
$$

where

$$
\begin{gathered}
a_{\mathrm{p}}(\lambda)=a_{\text {phy }}(\lambda)+a_{\text {hbact }}(\lambda)+a_{\text {det }}(\lambda) \\
b_{\text {btot }}(\lambda)=b_{\text {bw }}(\lambda)+b_{\text {bp }}(\lambda)
\end{gathered}
$$

where

$$
b_{\mathrm{bp}}(\lambda)=b_{\mathrm{b}-\mathrm{phy}}(\lambda)+b_{\mathrm{b}-\mathrm{hbact}}(\lambda)+b_{\mathrm{b}-\operatorname{det}}(\lambda)
$$

The subscripts w, p, CDOM, phy, hbact, and det are for pure seawater, particles, colored dissolved organic matter, phytoplankton, heterotrophic bacteria, and detritus, respectively. Because all optical quantities are functions of wavelength $\lambda$, this argument will be omitted from our notation for simplicity, unless specifically required. The parameter $b_{\mathrm{bw}}$ is taken as half of the scattering coefficient of pure seawater as tabulated by Smith and Baker [1981], and values for the absorption coefficient of pure water are from Pope and Fry [1997]. We assume that the contribution of CDOM to $b_{\text {btot }}$ is negligible. Large noncolored heterotrophs are ignored because of their well-known negligible contributions to backscattering [Morel and Ahn, 1991] and absorption. For the purpose of this study, which is to use satellite data, the microbial community includes the heterotrophic bacteria and the photosynthetic populations of Prochlorococcus, Synechococcus, picoeukaryotic, and nanoeukaryotic algae in water collected from the upper $10 \mathrm{~m}$ of the sea surface.

\subsubsection{Microbial Absorption}

[9] For estimation of microbial absorption, algal cells collected were assumed to be spherical and homogeneous.
For such cells, the dimensionless efficiency factor for absorption ( $Q$ a) was calculated as by Morel and Bricaud [1981]:

$$
Q \mathrm{a}=1+2 \mathrm{e}^{-\rho^{\prime}} / \rho^{\prime}+2\left(e^{-\rho^{\prime}}-1\right) / \rho^{\prime 2}
$$

where the dimensionless parameter $\rho^{\prime}$ is defined as

$$
\rho^{\prime}=a_{\mathrm{sol}}^{*} c_{\mathrm{i}} D
$$

$\mathrm{D}$ is the cell diameter (in meters), $c_{\mathrm{i}}$ is the intracellular pigment concentration per unit of cell volume $\left(\mathrm{kg} \mathrm{m}^{-3}\right)$, and $a_{\mathrm{sol}}^{*}$ is the specific absorption coefficient for chlorophyll $a$ in solution $\left(\mathrm{m}^{2} \mathrm{~kg}\right.$ chl $\left.a^{-1}\right)$ (taken here as $27,000 \mathrm{~m}^{2} \mathrm{~kg} \operatorname{chl} a^{-1}$ as by Sosik and Mitchell [1991]). The mean diameter of cells was derived from the Forward Angle Light Scattering (FALS) measured by flow cytometry as by Blanchot et al. [2001]. This diameter was estimated to vary between 0.64 and $0.84 \mu \mathrm{m}$ for Prochlorococcus and estimated to be $1.5 \mu \mathrm{m}$ for picoeukaryotic algae. For nanoeukaryotic phytoplankton ( $>2-\mu \mathrm{m}$ cell diameter), abundances, biovolumes, and carbon contents were assessed from microscopic determinations of cell diameter and size as described above. The intracellular pigment concentration of each size category was determined by dividing the pigment concentration associated with each group by the summed cell biovolume. For Prochlorococcus, we used the measured concentration of dv-chl $a$. For Synechococcus, picoeukaryotes and nanoeukaryotes, the concentration of chl $a\left(C_{\mathrm{i}}, \mathrm{mg} \mathrm{m}^{-3}\right)$ was partitioned on the basis of the relative contributions of each population to estimated microbial carbon. This assumes that the cellular chl:carbon ratios were the same for each group. With the fractionated chl $a$ and the biovolumes of each group, it was then possible to calculate the intracellular pigment concentrations associated with Synechococcus, picoeukaryotes and nanoeukaryotes. Despite their high abundance, heterotrophic bacteria were generally not included in the absorption calculations because of their negligible absorptional cross sections [Morel and Ahn, 1990]. However, an estimate of their contribution to total microbial absorption was made along the transect on the basis of cross-section absorption estimates of Stramski et al. [2001].

[10] For each group, we calculated the dimensionless $Q^{*}$, a factor (the "package effect") which expresses the tendency of the absorption coefficient to flatten when size and intracellular concentration increase. These were determined according to Morel and Bricaud [1981] as

$$
Q^{*} \mathrm{a}=3 / 2 Q \mathrm{a} / \rho^{\prime}
$$

The absorption coefficient for each group was then calculated as

$$
a_{\mathrm{i}}=a_{\mathrm{sol}}^{*} * Q_{\mathrm{ai}}^{*} * C_{\mathrm{i}}
$$

where $C_{\mathrm{i}}$ is the pigment concentration $\left(\mathrm{mg} \mathrm{m}^{-3}\right)$ (i.e., chl $a$ associated with Synechococcus, picoeukaryotes and nanoeukaryotes, and dv-chl a with Prochlorococcus). Then, we calculated $a_{\text {mic }}$ as

$$
a_{\text {mic }}=a_{\text {pro }}+a_{\text {syn }}+a_{\text {peuk }}+a_{\text {naneuk }}
$$

[11] The absorption simulation was done at $670 \mathrm{~nm}$. The absorption coefficient at $440 \mathrm{~nm}$ was then estimated using 
the measured (440)-to-red (670) ratio (B/R) of $a_{\text {phy }}$ along the transect, and assuming that this global measured $\mathrm{B} / \mathrm{R}$ ratio was representative of all populations.

\subsubsection{Microbial Backscattering}

[12] Backscattering contributions of photosynthetic organisms and heterotrophic bacteria were estimated as

$$
b_{\mathrm{b}-\mathrm{mic}}(\lambda)=\sum_{j=1}^{4} \mathrm{~N}_{\mathrm{j}} \cdot\left(\sigma b_{\mathrm{b}}(\lambda)\right)_{\mathrm{j}}
$$

where the subscript $\mathrm{j}$ describes one of the microbial components as defined above, $N_{\mathrm{j}}$ is the number of particles per unit volume of seawater for each microbial component, and $\left(\sigma b_{\mathrm{b}}(\lambda)\right)_{\mathrm{j}}$ is the mean particle cross-sectional backscattering for each component $\left(\mathrm{m}^{2}\right.$ particle $\left.{ }^{-1}\right)$. The latter were taken from Stramski and Mobley [1997] assuming that these published data (i.e., heterotrophic bacteria (BACT), Synechococcus (CYA), Prochlorococcus (PROC), Thalassiosira pseudonana (PSEU) and Dunaliella tertiolecta (TER) for nanoeucaryotes) were representative of the studied populations and assuming that backscattering of picoeucaryotes was negligible.

\subsection{Retrieval of chl, $a(\lambda)$ and $b_{\mathrm{b}}(\lambda)$ From Ocean Color}

[13] The POLDER instrument [Deschamps et al., 1994] was launched onboard the Japanese platform ADEOS in August 1996. Eight months of data (November 1996 to June 1997) was acquired before the failure of the satellite's solar panel on 30 June 1997. POLDER is a multispectral radiometer $(443,490,565,670,765,865$, and $910 \mathrm{~nm})$ with directionality and polarization capabilities that enable a daily global coverage of the Earth at $7-\mathrm{km}$ resolution. The POLDER ocean color products include remote sensing of marine reflectance beneath the surface, $R_{\mathrm{rs}}$, at 443 , 490 and $565 \mathrm{~nm}$, chlorophyll $a$ concentration (chl), as well as atmospheric correction byproducts (e.g., aerosol optical thickness). Here we used the POLDER 10-day mean of marine reflectances to compute the mean pigment concentration over the EBENE area (Figure 1a). To do so, we first computed the normalized difference phytoplankton index (NDPI) [Frouin et al., 1998] as

$$
\mathrm{NDPI}=\left(R_{\mathrm{rs} 443}-R_{\mathrm{rs} 565}\right) / R_{\mathrm{rs} 490}
$$

and then estimated the pigment concentration (Csat) (Figure 1b) using:

$$
\mathrm{C}_{\mathrm{sat}}=10^{(0.318-1.055 \times \mathrm{NDPI})}
$$

[14] We preferred the NDPI bio-optical algorithm because it uses $R_{\mathrm{rs} 443}$ rather than the OC2 that is generally used to estimate the standard POLDER Csat [O'Reilly et al., 1998]. The examination of POLDER marine reflectances along the EBENE transect indeed revealed a much stronger variability of $R_{\mathrm{rs}}$ at $443 \mathrm{~nm}$ in the equatorial upwelling region than at $490 \mathrm{~nm}$. This is not surprising since it is well known that $R_{\mathrm{rs} 443}$ is more sensitive than $R_{\mathrm{rs} 490}$ to variations in phytoplankton concentrations in oligotrophic and mesotrophic case I waters [e.g., Morel, 1988]. As a result, the Csat estimate by the NDPI algorithm yields a better agreement with in situ chlorophyll measurements.

[15] Owing to the recent development of inverse methods, it is now possible to derive the absorption $(a)$ and backscattering $\left(b_{\mathrm{b}}\right)$ coefficients within the upper ocean from remote sensing reflectance $\left(R_{\mathrm{rs}}\right)$ or normalized water-leaving radiance $\left(L_{\mathrm{wn}}\right)$ [Roesler and Perry, 1995; Lee et al., 1998; Loisel and Stramski, 2000]. For this study, we used the model developed by Loisel and Stramski [2000]. At a given wavelength $\lambda$ and solar zenith angle $\theta_{0}$, the model requires as input the diffuse attenuation of downwelling irradiance within the surface layer $\left(\left\langle K_{\mathrm{d}}\right\rangle_{1}\right)$ and the irradiance reflectance just beneath the sea surface, $R\left(0^{-}\right)$(see Table 1 for notation). The derivation of $a$ and $b_{\mathrm{b}}$ from this model accounts for Raman scattering which can significantly affect $R_{\mathrm{rs}}(\lambda)$ in oligotrophic waters. Moreover, this model shows relatively little sensitivity to changes in the scattering phase function, and to the vertical structure of the IOP profiles [Loisel and Stramski, 2000; Loisel et al., 2001]. The errors in $a$ and $b_{\mathrm{b}}$ were usually only a few percent $(<10 \%)$. The $a(\lambda)$ and $b_{\mathrm{b}}(\lambda)$ values predicted by the model in the bluegreen spectral region showed generally good agreement with in situ measurements under conditions ranging from clear oligotrophic waters to turbid coastal waters affected by river discharge [Loisel et al., 2001].

[16] For ocean color remote sensing applications, only the normalized water-leaving radiance, $L_{\mathrm{WN}}$, is available. The procedure to retrieve $R\left(\lambda, 0^{-}\right)$and $\left\langle K_{\mathrm{d}}(\lambda)\right\rangle_{1}$ from $L_{\mathrm{WN}}$ was described in detail by Loisel et al. [2001]. The application of our inversion method to determine $a$ and $b_{\mathrm{b}}$, when both $R\left(\lambda, 0^{-}\right)$and $\left\langle K_{\mathrm{d}}(\lambda)\right\rangle_{1}$ are obtained from $L_{\mathrm{WN}}$, was also successfully tested against in situ data [Loisel et al., 2001]. Note that our model is independent of the spectral shape of $a$ and $b_{\mathrm{b}}$, and only assumptions about the calculation of $\left\langle K_{\mathrm{d}}(\lambda)\right\rangle_{1}$ from $R\left(\lambda, 0^{-}\right)$are needed. However, we showed that the spectral values of $\left\langle K_{\mathrm{d}}(\lambda)\right\rangle_{1}$ calculated from reflectance agree well with direct determinations of $\left\langle K_{\mathrm{d}}(\lambda)\right\rangle_{1}$ from in situ measurements performed in various oceanic waters.

\section{Results}

\subsection{POLDER Satellite Surface Pigments}

[17] The POLDER Csat composite image corresponding to the EBENE cruise is shown in Figure 1a. The equatorial chlorophyll enrichment in the Pacific Ocean shows its maximal meridional extension at the north and south of the equator as the chlorophyll-rich tongue spans 13 degrees in latitude (from about $7^{\circ} \mathrm{S}$ to $6^{\circ} \mathrm{N}$ ). Such an extreme situation has been previously described [Dupouy et al., 1993; Murakami et al., 2000; Radenac et al., 2001]. The distribution was asymmetrical with respect to the $0^{\circ}-4^{\circ} \mathrm{N}$ Csat maximum, showing a sharp decrease at $5^{\circ} \mathrm{N}$ and a broader decrease from 0 to $8^{\circ} \mathrm{S}$ (Figure $1 \mathrm{~b}$ ).

\subsection{Measured Parameters From Field}

[18] The in situ average Tchl $a$ concentration within the upper 5-20 $\mathrm{m}$ (Figure 1b) shows maxima between $2^{\circ} \mathrm{S}$ and $4^{\circ} \mathrm{N}$, corresponding to a broad Tchl $a$ maximum from 0 to $100 \mathrm{~m}$ centered at the equator [Brown et al., 2003] (Figure 2a). This surface distribution coincides with the satellite pattern (Figure 1b). Eukaryotic chl $a$ was 50-60\% 

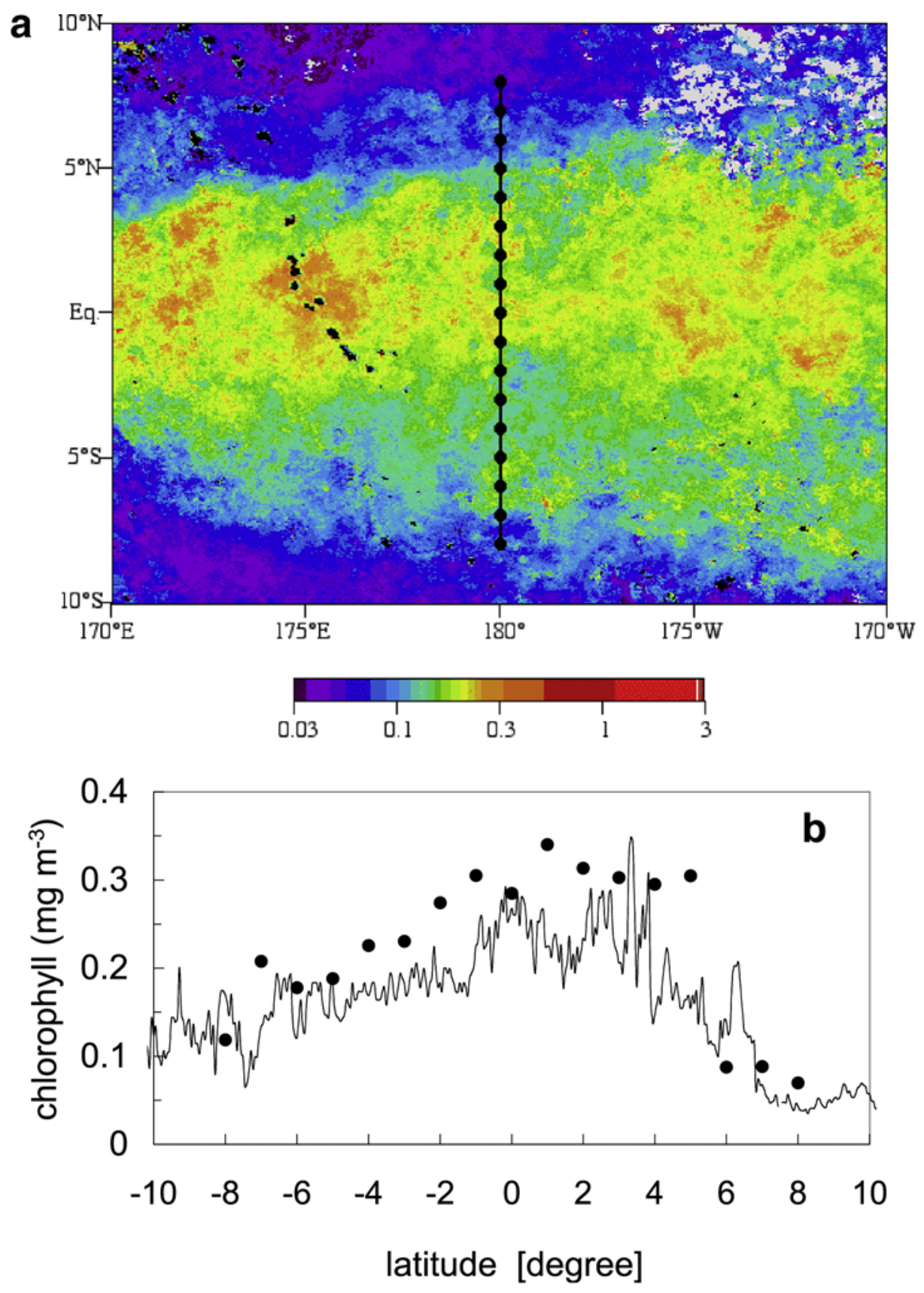

Figure 1. (a) Station locations of the $8^{\circ} \mathrm{N}-8^{\circ} \mathrm{S}$ transect along $180^{\circ}$ during the EBENE cruise (21 October 1996 to 2 November 1996) on the POLDER-ADEOS-1 composite image of chlorophyll (as calculated from the NDVI from $10^{\circ} \mathrm{N}$ to $10^{\circ} \mathrm{S}, 170^{\circ} \mathrm{E}$ to $170^{\circ} \mathrm{W}$ ). The Kiribati Islands archipelago is shown in black, approximately centered at the equator. (b) Surface $(5 \mathrm{~m})$ meridian distributions from $10^{\circ} \mathrm{S}$ to $10^{\circ} \mathrm{N}$ along the EBENE transect at $180^{\circ}$ of the satellite NDVI from POLDER (continuous line) and of the measured total chlorophyll $a$ (chl $a+\mathrm{dv}-\mathrm{chl} a)$ (solid circles).

of the Tchl $a$ between $6^{\circ} \mathrm{S}$ and $6^{\circ} \mathrm{N}$ and decreased to $40 \%$ at $8^{\circ} \mathrm{N}$ and $8^{\circ} \mathrm{S}$ corresponding to the composition of phytoplankton which varied with latitude (Figure 2a) [see also Brown et al., 2003]. The picoeukaryotes averaged about $1.7 \times 10^{3}$ cells $\mathrm{mL}^{-1}$ and showed a maximal abundance $\left(5 \times 10^{3}\right.$ cells $\left.\mathrm{mL}^{-1}\right)$ between $2^{\circ}-3^{\circ} \mathrm{S}$ and the equator. Nanoeukaryotes $(2-20 \mu \mathrm{m})$ were most abundant between the equator and $5^{\circ} \mathrm{N}\left(4.6 \times 10^{3}\right.$ cells $\left.\mathrm{mL}^{-1}\right)$. All groups showed minima between 6 and $8^{\circ} \mathrm{N}$. Prochlorococcus abundance increased gradually from $8^{\circ} \mathrm{S}(1.3 \times$
$10^{5}$ cells $\mathrm{mL}^{-1}$ ) to $1^{\circ}-3^{\circ} \mathrm{S}$ (maximum of $3 \times 10^{5}$ cells $\mathrm{mL}^{-1}$ at $1^{\circ} \mathrm{S}$ ) and decreased sharply toward $8^{\circ} \mathrm{N}$ (minimum abundance of $0.7 \times 10^{5}$ cells $\mathrm{mL}^{-1}$ ). Synechococcus abundance was also maximal at $1^{\circ}-3^{\circ} \mathrm{S}(2.2 \times$ $10^{4}$ cells $\mathrm{mL}^{-1}$ ) and decreased to $1.4 \times 10^{3}$ cells $\mathrm{mL}^{-1}$ at $6^{\circ} \mathrm{N}$. Heterotrophic bacteria peaked at $3^{\circ} \mathrm{S}$ $\left(1.1 \times 10^{6}\right.$ cells $\left.\mathrm{mL}^{-1}\right)$ and decreased to $3 \times 10^{5}$ cells $\mathrm{mL}^{-1}$ at $8^{\circ} \mathrm{N}$ [Brown et al., 2003]. The relative numerical abundance of Prochlorococcus on total phytoplankton was highest at $8^{\circ} \mathrm{S}$ and from $6^{\circ} \mathrm{N}$ to $8^{\circ} \mathrm{N}$. 
Table 1. Notation

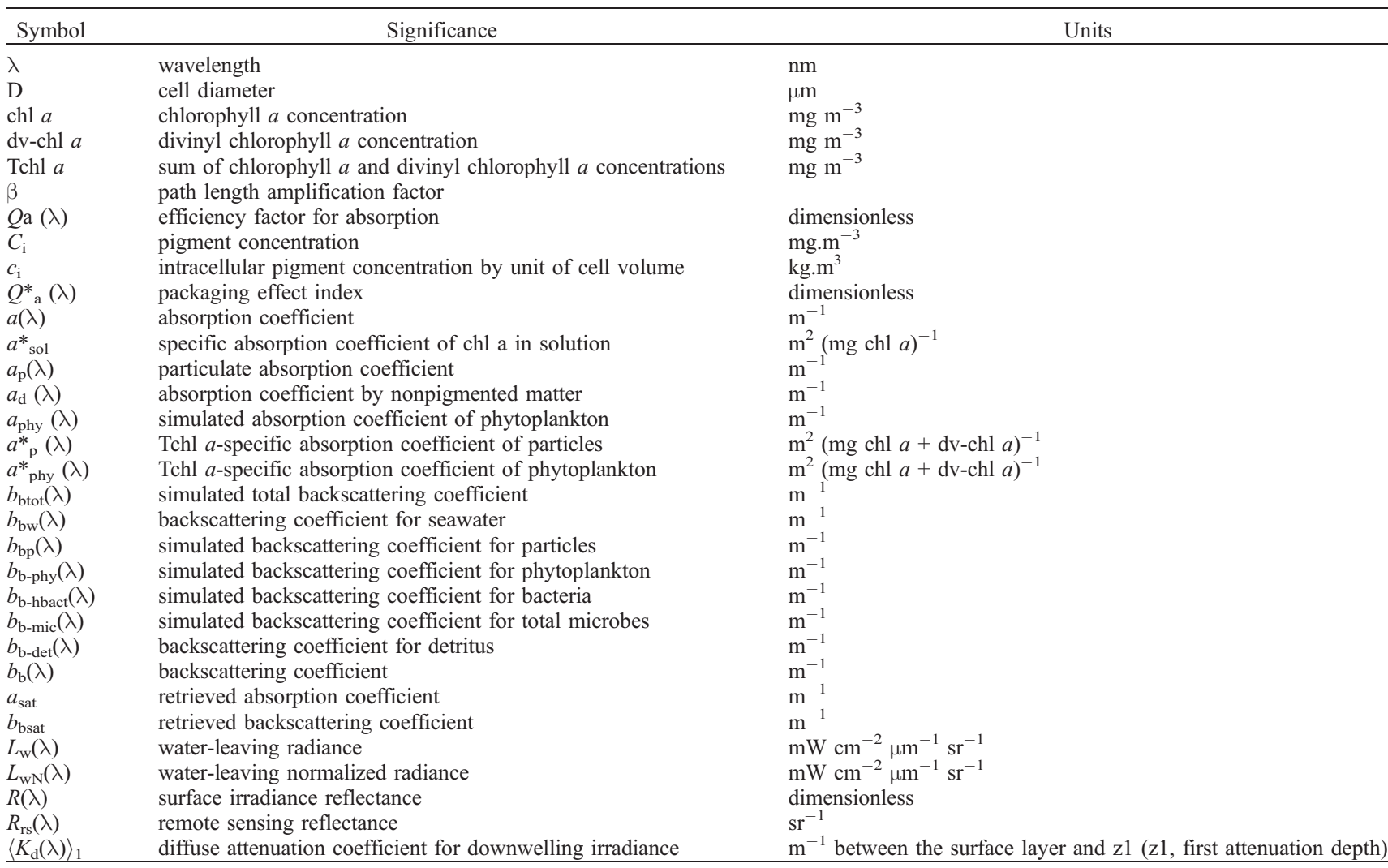

[19] The measured coefficient $a_{\text {phy }}(440)$ was tightly correlated with Tchl $a$ for the whole data set $(\mathrm{r}=0.865, \mathrm{~N}=$ 139) or for the sole surface samples $(\mathrm{r}=0.90, \mathrm{~N}=17)$. Measured values of the chlorophyll-specific absorption coefficient, $a_{\mathrm{phy}}^{*}(440)=a_{\mathrm{phy}}(440) / \mathrm{Tchl} a$ (Figure $\left.2 \mathrm{~b}\right)$ are highest at $8^{\circ} \mathrm{S}$ and $8^{\circ} \mathrm{N}\left(0.12 \mathrm{~m}^{2} \mathrm{mg}\right.$ chl $\left.a^{-1}\right)$ in association with a dv-chl $a$ : Tchl $a$ ratio $(0.61-0.64)$, reflecting the dominance of Prochlorococcus to phytoplankton biomass (Figure 2a). Surface measurements of the $a_{\mathrm{p}}$ (440) (Figure $2 \mathrm{c}$ ) showed relatively high values over nine degrees of latitude $\left(4^{\circ} \mathrm{S}\right.$ to $\left.5^{\circ} \mathrm{N}\right)$ (see also Figure 3a). This coefficient is mainly influenced by the contribution of algal particles; detritus particles representing on average $14 \%$ of $a_{\mathrm{p}}$ in the surface layer, with a minimum of $10 \%$ at the equator and a maximum of $50 \%$ at $8^{\circ} \mathrm{S}$. Minimum values of $a_{\mathrm{phy}}^{*}\left(0.06 \mathrm{~m}^{2}\right.$ $(\mathrm{mg} \text { Tchl } a)^{-1}$ ) were found at $6^{\circ} \mathrm{S}$ and $2^{\circ} \mathrm{S}$ and are typical of chlorophyll-enhanced conditions in the equatorial upwelling zone [Lindley et al., 1995; Dupouy et al., 1997; Allali et al., 1997]. The model [Bricaud et al., 1998] which relates $a^{*}$ phy to Tchl $a$ concentration also produces low values of $a^{*}$ phy between $6^{\circ} \mathrm{S}$ and $4^{\circ} \mathrm{N}$ and higher values at $8^{\circ} \mathrm{S}$ and $8^{\circ} \mathrm{N}$. Depth distributions of the absorption coefficients in meridional transects from $8^{\circ} \mathrm{S}$ and $8^{\circ} \mathrm{N}(0$ to $160 \mathrm{~m})$ are shown in Figures 3 and 4. The influence of the rich chlorophyll maximum at $60 \mathrm{~m}$ [Brown et al., 2003] in the equatorial upwelling is apparent for $a_{\mathrm{p}}, a_{\mathrm{det}}$, and $a_{\mathrm{phy}}$ coefficients. Detrital contributions (with a high value of $0.003 \mathrm{~m}^{-1}$ for $a_{\text {det }}(440)$ between 10 and $100 \mathrm{~m}$ ) tended to increase with depth, up to $50 \%$ below the chlorophyll maximum at $150 \mathrm{~m}$ around $2^{\circ} \mathrm{N}$ (Figures $3 \mathrm{~b}$ and $3 \mathrm{c}$ ). The absorption coefficient of phytoplankton at $440 \mathrm{~nm}, a_{\mathrm{phy}}$, was more homogeneous with depth than $a_{\mathrm{p}}(440)$, with values above $0.018 \mathrm{~m}^{-1}$ around the equator (Figure $4 \mathrm{a}$ ). The lowest blue (440)-to-red (670) ratios of $a_{\mathrm{p}}$ (Figure 4c) were found under the chlorophyll maximum and the highest $\mathrm{B} / \mathrm{R}(5)$ and $a_{\mathrm{phy}}^{*}(440)$ values $\left(0.12 \mathrm{~m}^{2} \mathrm{mg} \operatorname{chl} a^{-1}\right)$ (Figure $4 \mathrm{~b}$ ) were found at the surface in the extreme ends of the transect.

\subsection{Retrieved Versus Measured Coefficients \\ 3.3.1. Absorption}

[20] The POLDER-retrieved absorption coefficient $\left(a_{\text {sat }}\right.$ at $443 \mathrm{~nm}$ ), over all pixels from $10^{\circ} \mathrm{S}$ to $10^{\circ} \mathrm{N}, 180^{\circ}$, varied from $0.0104 \mathrm{~m}^{-1}\left(8^{\circ} \mathrm{N}\right)$ to $0.0305 \mathrm{~m}^{-1}$ at the equator

Figure 2. (opposite) Meridional transects from $10^{\circ} \mathrm{S}$ to $10^{\circ} \mathrm{N}$ and at $180^{\circ}$ of surface parameters for a comparison of measured and retrieved inherent properties $\left(a_{\mathrm{p}}, b_{\mathrm{bp}}\right)$ from the inversion of the POLDER NDVI composite image (110 November 1996) at $440 \mathrm{~nm}$. (a) Phytoplankton and bacterial cell abundances with Prochlorococcus abundance divided by 10 (triangles), Synechococcus (diamonds), picoeukaryotes (small squares), nanoeukaryotes (asterisks), and heterotrophic bacteria (solid squares). (b) Measured Tchl $a$-specific absorption coefficient of phytoplankton and modeled from Bricaud et al. [1998]. (c) Absorption coefficient ( $\left.a_{\text {sat }}\right)$ of the sum of the particles + CDOM retrieved from the inversion (line) and measured absorption by particles (solid circles). (d) Backscattering coefficient by particles $\left(b_{\mathrm{bp}}\right)$ retrieved from the inversion model (line) and as calculated from Morel [1988] (solid squares) and from Morel and Maritorena [2001] (solid diamonds). 


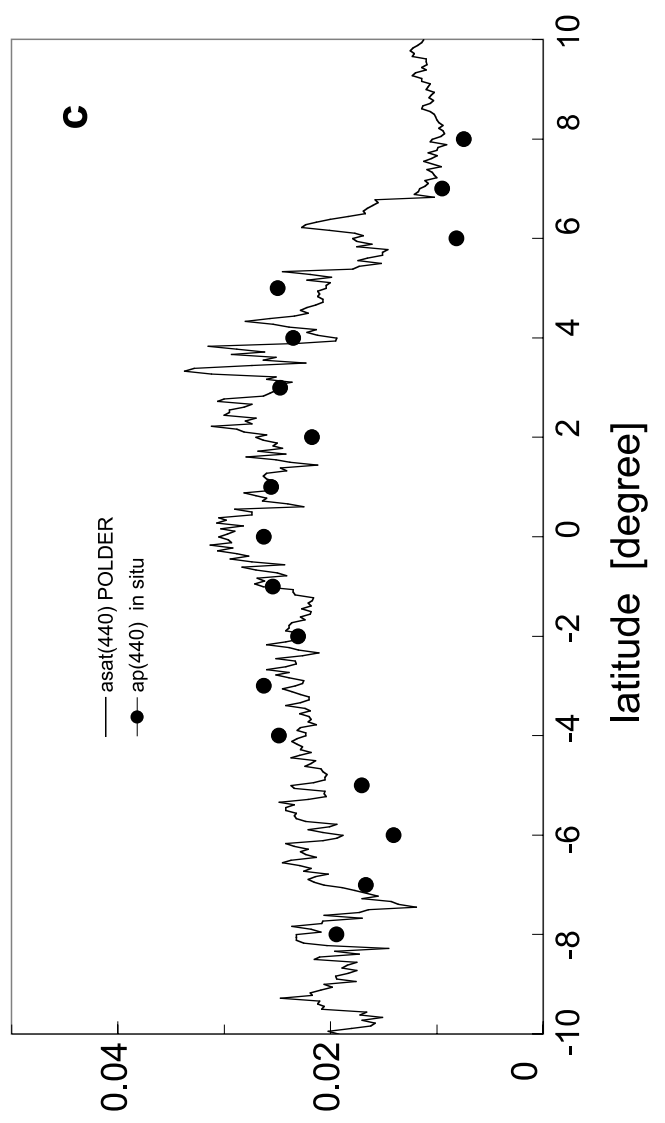

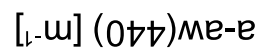

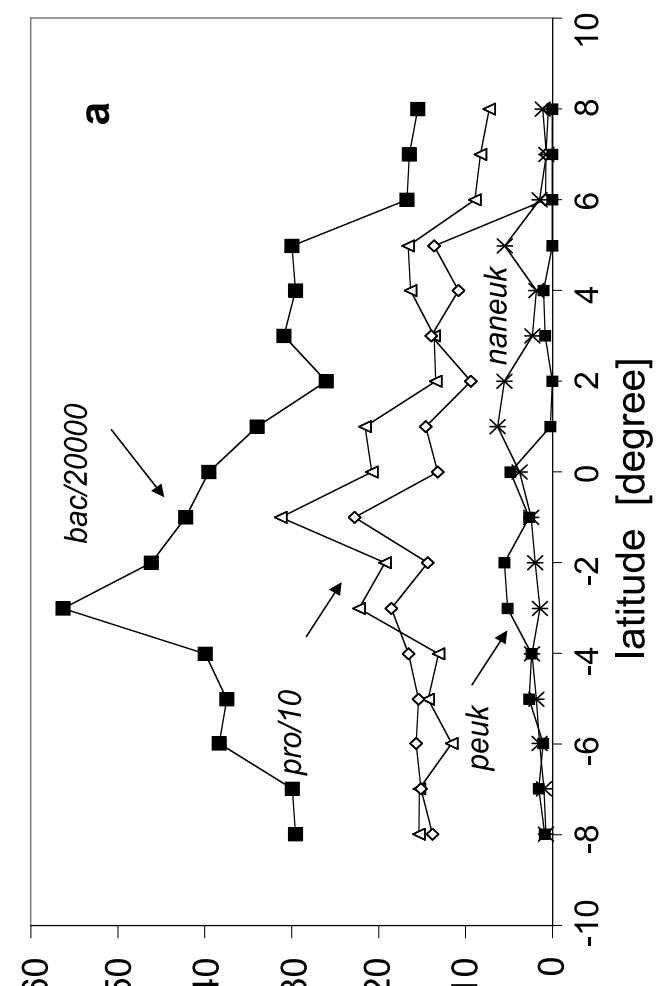

8 i ㅇ 요 응

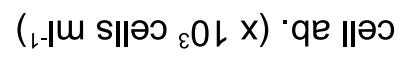
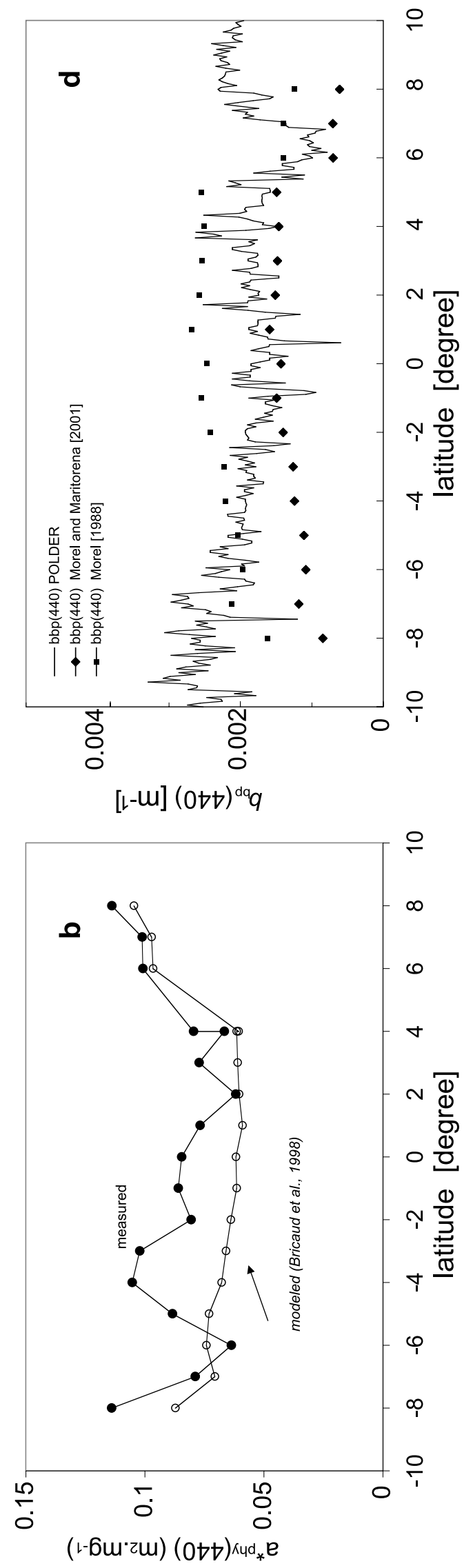
$180^{\circ} \mathrm{E}, 8^{\circ} \mathrm{S}-8^{\circ} \mathrm{N}, 26 / 10-13 / 11,1996$ $\operatorname{ap}(440)\left(m^{-1}\right)$
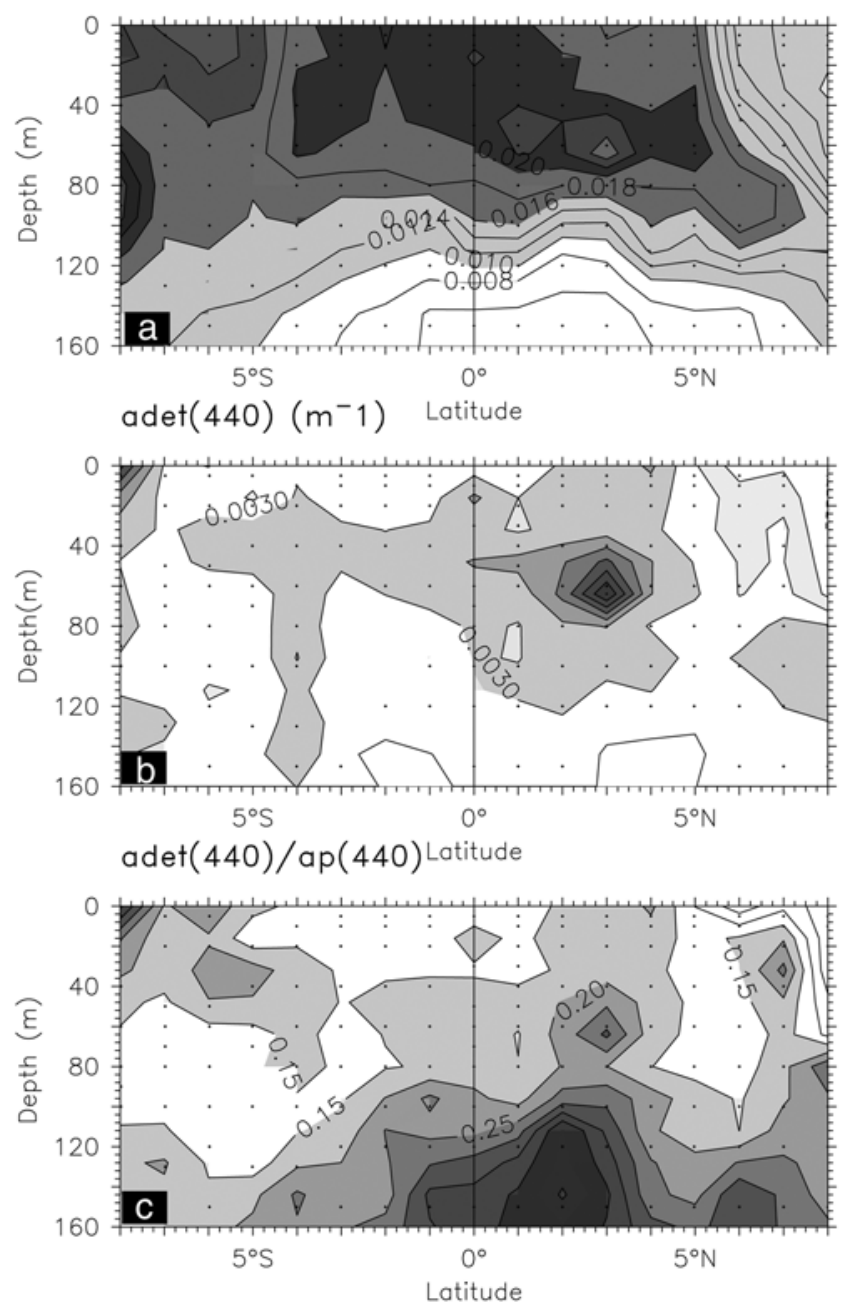

Figure 3. Meridional transects from $8^{\circ} \mathrm{S}$ to $8^{\circ} \mathrm{N}, 180^{\circ}$ during the transect of the EBENE cruise: (a) total particulate $a_{\mathrm{p}}(440) \mathrm{m}^{-1}$, (b) detrital $a_{\mathrm{d}}(440) \mathrm{m}^{-1}$, and (c) ratio of $a_{\mathrm{det}}$ (440) over $a_{\mathrm{p}}(440)$.

(Figure 2c). This coefficient represents the combined effects of particulate (phytoplankton + detritus) and dissolved materials after subtracting the contribution of pure water $\left(a_{\mathrm{w}}=0.0063 \mathrm{~m}^{-1}\right)$. The POLDER-retrieved absorption, $a_{\mathrm{sat}}$, and the measured absorption for particles, $a_{\mathrm{p}}$, show the same surface distribution patterns (Figure 2c). However, $a_{\text {sat }}$ is generally higher than $a_{\mathrm{p}}$. Assuming that the errors in the measurement retrieval are small, this discrepancy could be due to dissolved materials that contribute to $a_{\text {sat }}$ and not to $a_{\mathrm{p}}$. The average value and standard deviation of the contribution of dissolved material to $\left(a_{\mathrm{sat}}+a_{\mathrm{w}}\right)$ are $15 \%$ and $10 \%$, respectively. The maximum contribution is found at the higher latitudes explored during the cruise, whereas the minimum values are found around the equator.

\subsubsection{Backscattering}

[21] The POLDER-retrieved particle backscattering coefficient at $440 \mathrm{~nm}, b_{\mathrm{bp}-\mathrm{sat}}$, was compared to the $b_{\mathrm{bp}}$ values calculated using the semianalytical (or semiempirical) models of Morel [1988] and Morel and Maritorena [2001] and measured Tchl $a$ for EBENE stations (Figure 2d). The distribution of $b_{\mathrm{bp}-\text { sat }}$ along the transect shows a flat distribution along the latitudes except at $6^{\circ} \mathrm{N}$ where it drops. High values are found at the extreme parts of the transect, in opposition to values calculated by the semi analytical models [Morel, 1988; Morel and Maritorena, 2001]. It should be noted that the $b_{\mathrm{bp} \text {-sat }}$ values are always confined between the values obtained from the two semianalytical models.

\subsection{Simulated Versus Measured Absorption Coefficients}

[22] The package effect at $670 \mathrm{~nm}$, calculated at the shallowest depth for all microbial groups $\left(\mathrm{Q}_{\mathrm{a}}^{*}\right.$, Table 2), was minimal and constant from the south to the north of the EBENE transect for Synechococcus and picoeukaryotes. The $Q_{a}^{*}$ decreased in the northern part of the transect for Prochlorococcus. For nanoeukaryotes (mean diameter $=$ 3.4- $\mu \mathrm{m})$, the $Q_{a}^{*}(670)$ varied between 0.93 and 0.96 with
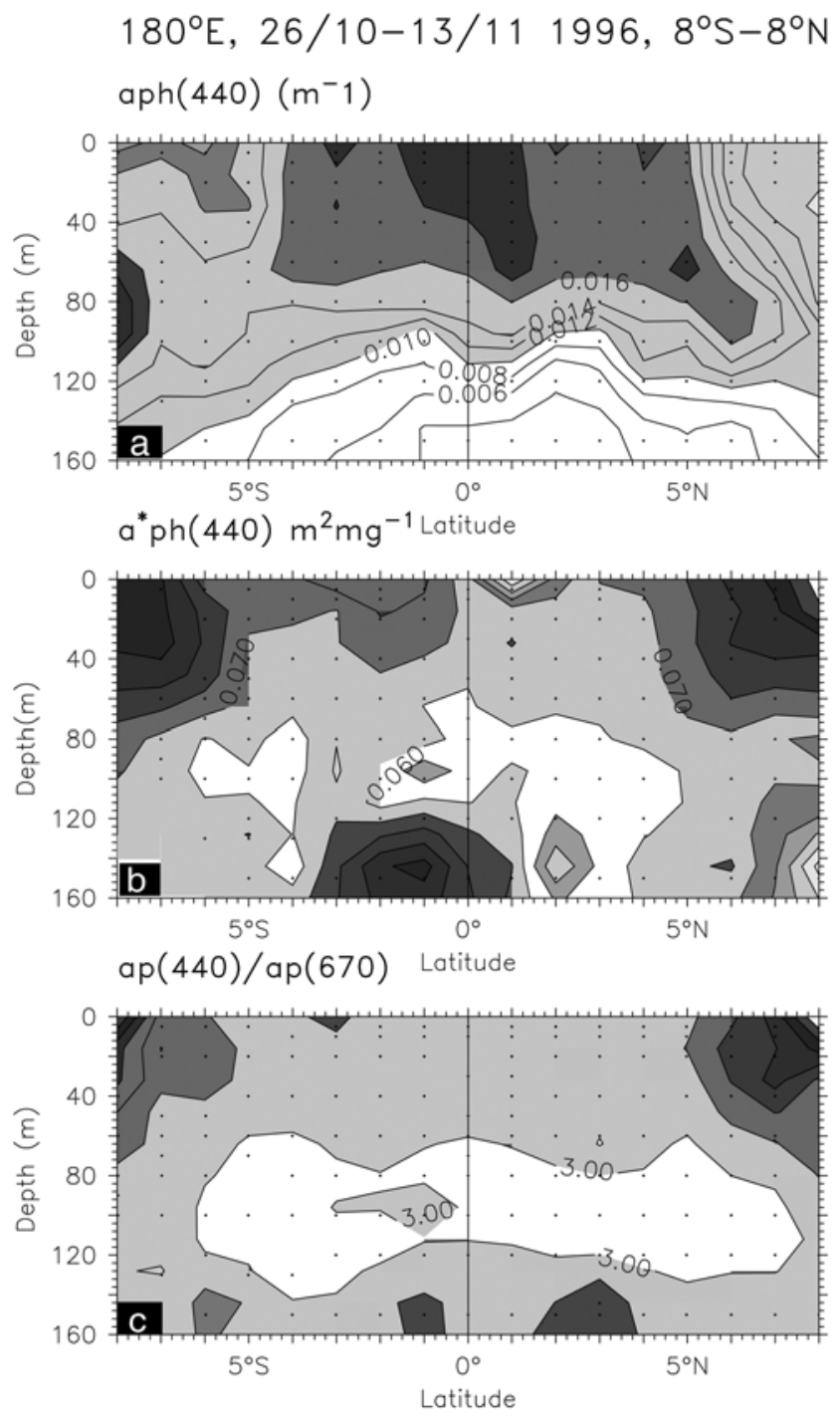

Figure 4. Meridional transects from $8^{\circ} \mathrm{S}$ to $8^{\circ} \mathrm{N}, 180^{\circ}$ during the transect of the EBENE cruise. (a) Phytoplankton absorption coefficient $a_{\text {phy }}(440)$ in $\mathrm{m}^{-1}$, (b) phytoplankton specific absorption coefficient $a_{\mathrm{phy}}^{*}(440)$ in $\mathrm{m}^{2}(\mathrm{mg}$ (Tchl $a))^{-1}$, and (c) ratio of $a_{\text {phy }}(440)$ to $a_{\text {phy }}(670)$. 
Table 2. Prochlorococcus (Pro), Synechococcus (Syn), Picoeukaryotes (Peuk), and Nanoeukaryotes (Neuk) in the Surface Waters Along the EBENE Transect at $180^{\circ}$ From $8^{\circ} \mathrm{S}$ to $8^{\circ} \mathrm{N}$ in the Equatorial Pacific Ocean ${ }^{\mathrm{a}}$

\begin{tabular}{|c|c|c|c|c|c|c|c|c|c|c|c|c|}
\hline \multirow[b]{2}{*}{ Latitude } & \multicolumn{4}{|c|}{$\mathrm{D}, \mu \mathrm{m}$} & \multicolumn{4}{|c|}{$c_{\mathrm{i}}, \mathrm{kg} \mathrm{m}^{3}$} & \multicolumn{4}{|c|}{$\mathrm{Q} * a(670)$} \\
\hline & Pro & Syn & Peuk & Neuk & Pro & Syn & Peuk & Neuk & Pro & Syn & Peuk & Neuk \\
\hline $8^{\circ} \mathrm{S}$ & 0.73 & 1.04 & 1.50 & 3.92 & 2.05 & 1.26 & 1.77 & 1.32 & 0.99 & 0.99 & 0.97 & 0.95 \\
\hline $7^{\circ} \mathrm{S}$ & 0.73 & 1.06 & 1.50 & 3.50 & 3.05 & 2.33 & 3.53 & 2.79 & 0.98 & 0.98 & 0.95 & 0.91 \\
\hline $6^{\circ} \mathrm{S}$ & 0.82 & 1.06 & 1.50 & 3.50 & 2.26 & 1.75 & 2.58 & 1.99 & 0.98 & 0.98 & 0.96 & 0.93 \\
\hline $5^{\circ} \mathrm{S}$ & 0.81 & 1.09 & 1.50 & 4.44 & 2.10 & 0.71 & 1.09 & 0.89 & 0.98 & 0.99 & 0.98 & 0.96 \\
\hline $4^{\circ} \mathrm{S}$ & 0.81 & 1.09 & 1.50 & 3.54 & 2.80 & 1.25 & 1.94 & 1.58 & 0.98 & 0.99 & 0.97 & 0.95 \\
\hline $3^{\circ} \mathrm{S}$ & 0.73 & 0.98 & 1.50 & 3.34 & 2.38 & 2.56 & 3.04 & 2.42 & 0.98 & 0.98 & 0.95 & 0.92 \\
\hline $1^{\circ} \mathrm{S}$ & 0.82 & 1.02 & 1.50 & 3.36 & 1.54 & 1.93 & 2.60 & 2.04 & 0.99 & 0.98 & 0.96 & 0.93 \\
\hline $\mathrm{Eq}$ & 0.67 & 0.99 & 1.50 & 3.34 & 3.46 & 1.76 & 2.19 & 1.70 & 0.98 & 0.98 & 0.97 & 0.94 \\
\hline $1^{\circ} \mathrm{N}$ & 0.75 & 0.98 & 1.50 & 3.10 & 3.24 & 1.47 & 3.07 & 1.41 & 0.98 & 0.99 & 0.95 & 0.96 \\
\hline $2^{\circ} \mathrm{N}$ & 0.65 & 0.92 & 1.50 & 3.28 & 7.14 & 1.79 & & 1.39 & 0.95 & 0.98 & & 0.96 \\
\hline $3^{\circ} \mathrm{N}$ & 0.70 & 1.03 & 1.50 & 3.80 & 5.45 & 1.84 & 2.49 & 1.89 & 0.96 & 0.98 & 0.96 & 0.93 \\
\hline $4^{\circ} \mathrm{N}$ & 0.78 & 0.94 & 1.50 & 3.38 & 3.79 & 1.55 & 1.61 & 1.25 & 0.97 & 0.99 & 0.97 & 0.96 \\
\hline $5^{\circ} \mathrm{N}$ & 0.64 & 0.90 & 1.50 & 3.14 & 6.30 & 1.93 & & 1.42 & 0.96 & 0.98 & & 0.96 \\
\hline $6^{\circ} \mathrm{N}$ & 0.71 & 1.00 & 1.50 & 3.46 & 3.14 & 0.86 & & 0.88 & 0.98 & 0.99 & & 0.97 \\
\hline $8^{\circ} \mathrm{N}$ & & & 1.50 & 3.14 & & 1.08 & & 1.39 & & & & 0.96 \\
\hline
\end{tabular}

${ }^{\mathrm{a}}$ Estimated cell diameter $(D, \mu \mathrm{m})$, intracellular pigment concentration per cell volume $\left(\mathrm{ci}, \mathrm{kg} \mathrm{\textrm {m } ^ { 3 }}\right)$, and $Q_{\mathrm{a}}^{*}$ at $670 \mathrm{~nm}$.

minima at $7^{\circ} \mathrm{S}$ and $7^{\circ} \mathrm{N}$. The two major contributors to the absorption coefficient were Prochlorococcus and the nanoeukaryotes, the sum of their contributions accounting for almost all of the measured absorption for phytoplankton at $670 \mathrm{~nm}$. The estimated absorption coefficients were less than the measured values only at $5^{\circ} \mathrm{S}, 4^{\circ}$ and $3^{\circ} \mathrm{S}$ (Table 3 ). At these stations, other groups must have contributed more significantly to absorption. Assuming that the measured $\mathrm{B} / \mathrm{R}$ ratio can be used to estimate the absorption coefficient at $440 \mathrm{~nm}$ for different phytoplankton groups (prokaryotes and eukaryotes), $a_{\text {mic }} 440$ can be deduced from $a_{\text {mic }} 670$ (Table 3). Prochlorococcus and nanoeukaryotes contributed approximately equally (Figure 5a) to measured $a_{\text {phy }}$ (440), except at the ends of the transect where Prochlorococcus accounted for a higher proportion (60\%). As expected [Morel et al., 1993; Morel, 1997; Stramski and Kiefer, 1998], Synechococcus were minor absorbers (5\%) with a maximum of $10 \%$ in the southern part of the transect. Heterotrophic bacteria (because of their low absorption coefficient despite high numbers) were also minor absorbers and their mean contribution (as calculated using the absorption cross section of Stramski et al. [2001]) was $8 \%$ with a maximum of $15 \%$ at $5^{\circ} \mathrm{S}$.

\subsection{Simulated Versus Retrieved Backscattering Coefficients}

[23] Because no in situ backscattering measurements were made during the cruise, a comparison can only be made between the simulated and the POLDER-retrieved particle backscattering coefficients, $b_{\text {bmic }}$ and $b_{\text {bp-sat, }}$ respectively (Figure $2 \mathrm{~d}$ and Table 4 ). As seen, $b_{\text {bmic }}$ accounted for only $6 \%$ of $b_{\text {bp-sat }}$, which is consistent with previous studies. Thus most of the backscattering in oceanic waters is attributable to small and numerically abundant nonliving

Table 3. Absorption Coefficients at $670 \mathrm{~nm}$ for Prochlorococcus (Pro), Synechococcus (Syn), Picoeukaryotes (Peuk), and Nanoeukaryotes (Neuk) Compared to the Total Estimated, $a_{\text {mic }}$, and measured absorption coefficient of phytoplankton, $a_{\text {phy }}$, the in situ blue(440) to red(670) ratio, B/R, and the total estimated, $a_{\text {mic }}$, measured $a_{\text {phy }}$ and $a_{\mathrm{p}}$ (phytoplankton and particles) at $440 \mathrm{~nm}$, and retrieved $a_{\mathrm{p}}+a_{\mathrm{y}}(440)^{\mathrm{a}}$

\begin{tabular}{|c|c|c|c|c|c|c|c|c|c|c|c|}
\hline \multirow[b]{2}{*}{$\underline{\text { Latitude }}$} & \multicolumn{6}{|c|}{$670 \mathrm{~nm}$} & \multirow[b]{2}{*}{$\mathrm{B} / \mathrm{R}$} & \multicolumn{4}{|c|}{$440 \mathrm{~nm}$} \\
\hline & Pro & Syn & Peuk & Neuk & $a_{\mathrm{mic}}$ & $a_{\text {phy }}$ & & $a_{\mathrm{mic}}$ & $a_{\text {phy }}$ & $a_{\mathrm{p}}$ & Retr. $a_{\mathrm{p}}+a_{\mathrm{y}}$ \\
\hline $8^{\circ} \mathrm{S}$ & 0.0017 & 0.0003 & 0.0001 & 0.0008 & 0.0028 & 0.0025 & 4.82 & 0.0122 & 0.0121 & 0.0190 & 0.0232 \\
\hline $7^{\circ} \mathrm{S}$ & 0.0025 & 0.0006 & 0.0002 & 0.0015 & 0.0048 & 0.0053 & 2.78 & 0.0147 & 0.0148 & 0.0160 & 0.0206 \\
\hline $6^{\circ} \mathrm{S}$ & 0.0020 & 0.0004 & 0.0001 & 0.0017 & 0.0043 & 0.0034 & 3.12 & 0.0105 & 0.0104 & 0.0140 & 0.0188 \\
\hline $5^{\circ} \mathrm{S}$ & 0.0022 & 0.0002 & 0.0001 & 0.0020 & 0.0045 & 0.0054 & 2.76 & 0.0149 & 0.0151 & 0.0160 & 0.0237 \\
\hline $4^{\circ} \mathrm{S}$ & 0.0027 & 0.0004 & 0.0002 & 0.0022 & 0.0055 & 0.0067 & 3.28 & 0.0220 & 0.0221 & 0.0250 & 0.022 \\
\hline $3^{\circ} \mathrm{S}$ & 0.0028 & 0.0006 & 0.0007 & 0.0017 & 0.0058 & 0.0071 & 3.26 & 0.0231 & 0.0230 & 0.0260 & 0.023 \\
\hline $2^{\circ} \mathrm{S}$ & 0.0026 & 0.0003 & 0.0005 & 0.0029 & 0.0064 & 0.0066 & 3.01 & 0.0199 & 0.0198 & 0.0263 & 0.0233 \\
\hline $1^{\circ} \mathrm{S}$ & 0.0037 & 0.0006 & 0.0003 & 0.0025 & 0.0071 & 0.0072 & 3.23 & 0.0232 & 0.0234 & 0.0254 & 0.0263 \\
\hline $\mathrm{Eq}$ & 0.0030 & 0.0003 & 0.0005 & 0.0032 & 0.0070 & 0.0072 & 3.13 & 0.0225 & 0.0227 & 0.0263 & 0.0305 \\
\hline $1^{\circ} \mathrm{N}$ & 0.0040 & 0.0003 & 0.0000 & 0.0036 & 0.0079 & 0.0078 & 2.98 & 0.0233 & 0.0233 & 0.0256 & 0.026 \\
\hline $2^{\circ} \mathrm{N}$ & 0.0035 & 0.0002 & 0.0000 & 0.0036 & 0.0074 & 0.0066 & 2.67 & 0.0176 & 0.0176 & 0.0217 & 0.027 \\
\hline $3^{\circ} \mathrm{N}$ & 0.0035 & 0.0004 & 0.0001 & 0.0032 & 0.0071 & 0.0067 & 3.17 & 0.0213 & 0.0214 & 0.0247 & 0.0251 \\
\hline $4^{\circ} \mathrm{N}$ & 0.0040 & 0.0002 & 0.0001 & 0.0029 & 0.0071 & 0.0068 & 2.64 & 0.0181 & 0.0181 & 0.0235 & 0.0194 \\
\hline $5^{\circ} \mathrm{N}$ & 0.0038 & 0.0003 & 0.0000 & 0.0033 & 0.0073 & 0.0070 & 3.20 & 0.0223 & 0.0224 & 0.0250 & 0.0204 \\
\hline $6^{\circ} \mathrm{N}$ & 0.0014 & 0.0000 & 0.0000 & 0.0007 & 0.0021 & 0.0023 & 3.66 & 0.0083 & 0.0082 & 0.0082 & 0.0179 \\
\hline $7^{\circ} \mathrm{N}$ & 0.0013 & 0.0000 & 0.0000 & 0.0007 & 0.0020 & 0.0022 & 4.77 & 0.0103 & 0.0080 & 0.0095 & 0.0116 \\
\hline $8^{\circ} \mathrm{N}$ & & & & 0.0007 & & 0.0012 & & 0.0000 & 0.0074 & & 0.0104 \\
\hline
\end{tabular}

${ }^{\mathrm{a}}$ Absorption coefficient for the sum of particles and yellow substances $\left(a_{\mathrm{sat}}=a_{\mathrm{p}}+a_{\mathrm{y}}(440)\right)$, as retrieved from an inversion model by Loisel and Stramski [2000]. 

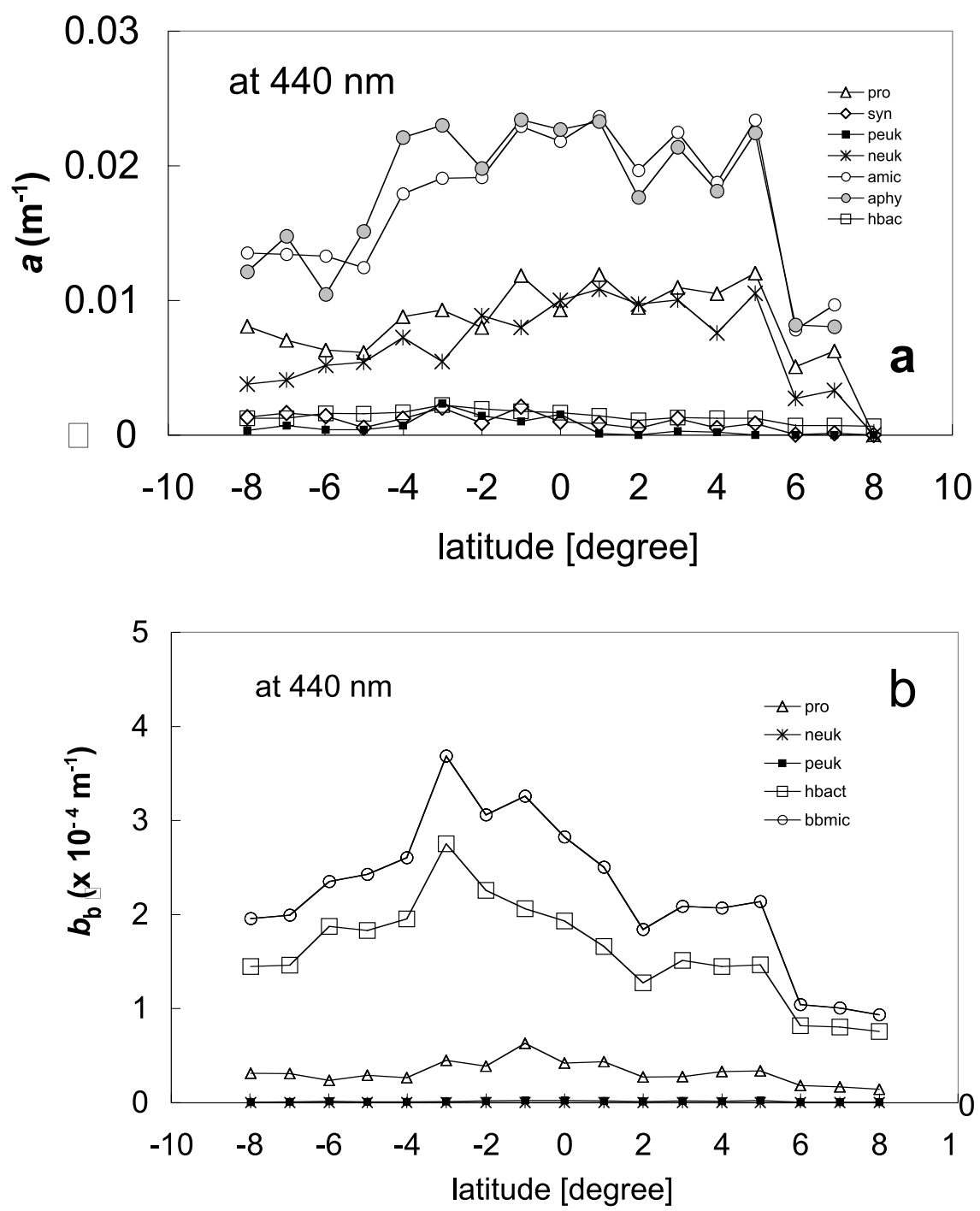

Figure 5. Results of the simulation of IOPs along the EBENE transect at $180^{\circ}$ from $10^{\circ} \mathrm{S}$ and $10^{\circ} \mathrm{N}$ for surface waters at $440 \mathrm{~nm}$. (a) Absorption coefficient, $a$ at $440 \mathrm{~nm}$, as estimated from the product of $\mathrm{Ci} \bullet$ $a_{\mathrm{sol}}^{*} \bullet \mathrm{Q}_{\mathrm{a}}^{*}\left(\mathrm{Q}_{\mathrm{a}}^{*}\right.$ is calculated from the cell sizes) of Prochlorococcus (triangles), Synechococcus (diamonds), picoeukaryotes (small solid squares), and nanoeukaryotes (asterisks). Absorption by heterotrophic bacteria (large open squares) as calculated from Stramski's absorption cross section. Microbial absorption, $a_{\text {mic }}$ (open circles) $=$ the sum of $a_{\text {pro }}+a_{\text {syn }}+a_{\text {peuk }}+a_{\text {neuk }}$, is compared to measured $a_{\text {phy }}(440)$ (gray circles). (b) Backscattering coefficient, $b_{\mathrm{b}}$ at $440 \mathrm{~nm}$, from Stramski and Mobley [1997] data with $b_{\text {bmic }}$ (open circles) calculated as the sum of $b_{\text {hbact }}+b_{\text {bpro }}+b b_{\text {peuk }}+b b_{\text {neuk }}$.

particles (also possibly viruses if present at a sufficiently high concentrations). Among the microbial populations evaluated, heterotrophic bacteria were the most important source of microbial backscattering (between $63 \%$ and $81 \%$ of $b_{\text {bmic }}$ at $1^{\circ} \mathrm{S}$ and $7^{\circ} \mathrm{N}$, respectively; Figure $5 \mathrm{~b}$ ). Their contribution averaged $73 \%$ of $b_{\mathrm{bmic}}$ and was highest between $4^{\circ} \mathrm{S}$ and the equator, where their concentrations were highest (peak at $3^{\circ} \mathrm{S}$ ). Backscattering contributions of other groups (Prochlorococcus, Synechococcus, and nanoeukaryotes simulated by the T.pseudonana of the Stramski's database) were $15 \%, 8 \%$ and $0.8 \%$ of $b_{\text {bmic }}$, respectively.

\section{Discussion}

[24] During the cold phase of the ENSO phenomenon, the high-nutrient, low-chlorophyll (HLNC) waters reach their maximal geographic extension to the west [Radenac et al., 2001; McClain et al., 2002]. Then, the transect at $180^{\circ}$ of the EBENE cruise and the POLDER image were both representative of enhanced microbial biomass concentrated in the upwelling region [Brown et al., 2003]. Because of the presence of the equatorial upwelling, the chlorophyll range was high along the transect, and the microbial composition showed a high variability [Brown et al., 2003] as it was during the FLUPAC cruise along the equator between $165^{\circ} \mathrm{E}$ and $150^{\circ} \mathrm{W}$ [Dupouy et al., 1997; Blanchot et al., 2001]. It was surprising that the surface distributions of Tchl $a$ and $a_{\mathrm{p}}$ (or $a_{\mathrm{mic}}$ ) along the transect differed between $5^{\circ} \mathrm{S}$ and $3^{\circ} \mathrm{S}$ (Figure $1 \mathrm{~b}$ and Figure $2 \mathrm{c}$ ) despite the coincidence in pigment and absorption in situ measurements. There, both $a_{\mathrm{p}}$ and $a_{\text {phy }}$ show maxima at both 670 and $440 \mathrm{~nm}$ wavelengths, that are not related to a maximal abundance of 
Table 4. Backscattering Coefficient at $440 \mathrm{~nm}$ Along $180^{\circ \mathrm{a}}$

\begin{tabular}{|c|c|c|c|c|c|c|}
\hline$\underline{\text { Latitude }}$ & $b_{\mathrm{b}-\mathrm{syn}}$ & $b_{\text {b-euk }}$ & $b_{\mathrm{b} \text {-pro }}$ & $b_{\text {b-hbact }}$ & $b_{\mathrm{b}-\mathrm{mic}}$ & Retr. $b_{\mathrm{bp}}$ \\
\hline $8^{\circ} \mathrm{S}$ & 0.00001 & 0.00001 & 0.00003 & 0.00014 & 0.00020 & 0.00268 \\
\hline $7^{\circ} \mathrm{S}$ & 0.00001 & 0.00001 & 0.00003 & 0.00015 & 0.00020 & 0.00273 \\
\hline $6^{\circ} \mathrm{S}$ & 0.00001 & 0.00001 & 0.00002 & 0.00019 & 0.00023 & 0.00215 \\
\hline $5^{\circ} \mathrm{S}$ & 0.00001 & 0.00002 & 0.00003 & 0.00018 & 0.00024 & 0.00217 \\
\hline $4^{\circ} \mathrm{S}$ & 0.00001 & 0.00002 & 0.00003 & 0.00020 & 0.00026 & 0.00193 \\
\hline $3^{\circ} \mathrm{S}$ & 0.00001 & 0.00003 & 0.00004 & 0.00028 & 0.00037 & 0.00178 \\
\hline $2^{\circ} \mathrm{S}$ & 0.00001 & 0.00003 & 0.00004 & 0.00023 & 0.00031 & 0.00193 \\
\hline $1^{\circ} \mathrm{S}$ & 0.00002 & 0.00004 & 0.00006 & 0.00021 & 0.00033 & 0.00188 \\
\hline $\mathrm{Eq}$ & 0.00001 & 0.00003 & 0.00004 & 0.00019 & 0.00028 & 0.00185 \\
\hline $1^{\circ} \mathrm{N}$ & 0.00001 & 0.00003 & 0.00004 & 0.00017 & 0.00025 & 0.00188 \\
\hline $2^{\circ} \mathrm{N}$ & 0.00001 & 0.00002 & 0.00003 & 0.00013 & 0.00018 & 0.00174 \\
\hline $3^{\circ} \mathrm{N}$ & 0.00001 & 0.00002 & 0.00003 & 0.00015 & 0.00021 & 0.00189 \\
\hline $4^{\circ} \mathrm{N}$ & 0.00001 & 0.00002 & 0.00003 & 0.00014 & 0.00021 & 0.00148 \\
\hline $5^{\circ} \mathrm{N}$ & 0.00001 & 0.00002 & 0.00003 & 0.00015 & 0.00021 & 0.00158 \\
\hline $6^{\circ} \mathrm{N}$ & 0.00000 & 0.00000 & 0.00002 & 0.00008 & 0.00010 & 0.000989 \\
\hline $7^{\circ} \mathrm{N}$ & 0.00000 & 0.00000 & 0.00002 & 0.00008 & 0.00010 & 0.00136 \\
\hline $8^{\circ} \mathrm{N}$ & 0.00000 & 0.00000 & 0.00001 & 0.00008 & 0.00009 & 0.00231 \\
\hline
\end{tabular}

${ }^{\mathrm{a}}$ Contributions of microbial groups to the total backscattering coefficient $b_{\mathrm{bmic}}$, cumulative $b_{\mathrm{b}}$ for Prochlorococcus + Synechococcus + small eukaryotes

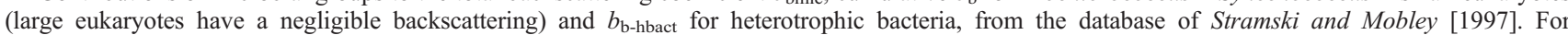
comparison the $b_{\mathrm{bp}}(440)$ was retrieved from the inversion of POLDER reflectances and the model by Loisel and Stramski [2000]. Note that the $b_{\mathrm{b}}$ of water is $0.0025 \mathrm{~m}^{-1}$ and that $b_{\mathrm{b}-\mathrm{det}}$ was not estimated.

total microbes, except of bacteria (which are poor absorbers, see below). This difference is also visible in the distribution of the modeled $a_{\mathrm{phy}}^{*}$ at $440 \mathrm{~nm}$ at these latitudes (which inversely follows the Tchl $a$ distribution) compared to the measured one (Figure $2 b$ ) and has no simple explanation. In surface waters of the equatorial Pacific sampled on the EBENE cruise, Prochlorococcus and nanoeukaryotes had the major influence on the absorption coefficient, accounting for $90 \%$ of $a_{\text {phy }}$ (at $670 \mathrm{~nm}$ and $440 \mathrm{~nm}$ ) in the northern part of the meridian transect $\left(1^{\circ} \mathrm{N}-8^{\circ} \mathrm{N}\right)$. This contribution of Prochlorococcus and nanoeukaryotes was reduced to $80 \%$ in the southern part, where heterotrophic bacteria and Synechococcus made a significant contribution of $15 \%$. Prochlorococcus and nanoeukaryotes showed equivalent contributions to the measured absorption coefficient. Recall that these results have been obtained by taking measured sizes and abundances from flow cytometer and microscopy, a constant chl a:carbon ratio for Synechococcus and picoeukaryotes and nanoeukaryotes, which is not always valid [Brown et al., 2003] and a global measured $\mathrm{B} / \mathrm{R}$ ratio which may not be adapted to the zeaxanthin-rich cyanobacteria [Morel et al., 1993] which would tend to underestimate the proportion of absorption by Prochlorococcus in the blue range. Moreover, this simulation exercise was only for surface waters, minimizing the effect of photoacclimation responses to reduced light with depth [Bricaud et al., 1999; Finkel, 2001; Dusenberry et al., 2001].

[25] The simulation of the absorption coefficients by the decomposition method is very sensitive to the mean size of each microbial group. Prochlorococcus and nanoeukaryotes, the main absorbing groups were characterized by small mean cell diameters ( 0.7 and $3.4 \mu \mathrm{m}$, respectively), low pigment content, and therefore low mean package effects (0.94 and 0.97, respectively). These calculated package effects for Prochlorococcus and nanoeukaryotic cells were of the same order as those measured previously in the surface layer of equatorial waters [Allali et al., 1997; Dupouy et al., 1997]. The cross sections of our major microbial groups were among the lowest observed, as compared with recently published data [Stramski et al., 2001]. At the equator, Prochlorococcus cell diameter varied between 0.52 and $0.82 \mu \mathrm{m}$, and dv-chl $a$ concentrations ranged between 0.4 and $1 \mathrm{fg} \mathrm{cell}^{-1}$. The cultured Prochlorococcus strain, $0.55 \mu \mathrm{m}$ in size, (MED 2 strain of Morel et al. [1993]) is similar to our surface Prochlorococcus population in its spectral shape and lack of dv-chl $b$, and its dv-chl $a$ content $\left(1.45 \mathrm{fg} \mathrm{cell}^{-1}\right)$ is equivalent to those measured in the equatorial Pacific (Table 2). Taking this last cross section for our calculation of the Prochlorococcus absorption coefficient would overestimate it in the rich chlorophyll waters. The estimation of the absorption coefficient for eukaryotes from database's cross sections would have lead to an even greater uncertainty. Dunaliella tertiolecta strain (denoted as TER), with a cell size of $7.5 \mu \mathrm{m}$ and cellular chl $a$ concentration of $1700 \mathrm{fg} \mathrm{cell}^{-1}$, is much too large to simulate the bulk absorption coefficient of our nanoeukaryotes $(2-20 \mu \mathrm{m})$. Even Thalassiosira pseudonana, $4 \mu \mathrm{m}$ in diameter with a cellular chl $a$ concentration of $390 \mathrm{fg} \mathrm{cell}^{-1}$ [Stramski and Mobley, 1997] would lead to an eukaryotic absorption coefficient too high by a factor of 6 . The smallest studied species, Nannochloris $(2-3 \mu \mathrm{m})$ [DuRand and Olson, 1998] or Micromonas pusilla $(1.8 \mu \mathrm{m})$ [DuRand et al., 2002], are in the range where absorption cross sections $\left(\sigma_{\mathrm{a}}\right)$, can be usefully compared. For Micromonas $s p$., the value of $\sigma_{\mathrm{a}}$ at $488 \mathrm{~nm}$ was $0.8 \mu \mathrm{m}^{2}$ and estimated as $1 \mu \mathrm{m}^{2}$ at $440 \mathrm{~nm}$. Assuming that this value represents nanoeukaryotes in this region, the absorption by this group approaches those calculated with equation (8). Indeed, the estimate of the absorption contribution of eukaryotes by equation (8) is quite robust. Another simulation with a unique eukaryotic population of sizes varying between 1.77 and $2.14 \mu \mathrm{m}$ gave similar results (with a mean difference of 3\%). Small populations such as those encountered in equatorial surface waters have yet to be isolated and their optical properties measured under nutrient and light regimes representative of surface in situ conditions.

[26] Detrital absorption was a minor component (13\%) of the total measured particulate absorption $a_{\mathrm{p}}(440)$. This 
seems to be a constant feature of equatorial waters [Bricaud et al., 1998] and has a direct impact on the modeling of remote-sensed reflectance from inherent optical properties [Bricaud et al., 2002]. The retrieved values of $a_{\text {sat }}(440)$ are consistent with the measured (and simulated) $a_{\mathrm{p}}$ values. The estimated absorption coefficient by CDOM is consistent with indirect estimates described by Bricaud et al. [1998]. It is only half of the in situ $<0.2 \mu \mathrm{m}$ $a_{\mathrm{CDOM}}(440)$ coefficient measured in the equatorial upwelling during the same ENSO cold phase (0.0013 in May 1996) [Simeon et al., 2003], which might be consistent considering that the CDOM absorption detected by the satellite is lower than the integrated $0-50 \mathrm{~m}$ value, partly because of photobleaching (J. Simeon, personal communication, 2003).

[27] The differences observed between $b_{\mathrm{bp}}$ as retrieved from the two semianalytical models, and $b_{\mathrm{bp}-\mathrm{sat}}$, particularly from $8^{\circ} \mathrm{S}$ to $0^{\circ}$, are due to the fact that the inverse method does not involve any assumptions about the relationship between $b_{\mathrm{bp}}$ and chl concentration, whereas the semianalytical models consider that $b_{\mathrm{bp}}$ is driven by chlorophyll concentration [Morel, 1988; Morel and Maritorena, 2001]. The main difference between these two models resides in the adoption of two distinct values of the backscattering efficiency for particles (see discussion by Morel and Maritorena [2001]). On the basis of theoretical considerations, Morel and Maritorena [2001] simply reset the maximal backscattering value at $1 \%$ instead of $2 \%$ as previously adopted by Morel [1988]. Such values must be confirmed with in situ backscattering measurements that can now be performed with the recent development of the Hydroscat-6 [Maffione and Dana, 1997]. Simulated microbial backscattering was mainly attributed to heterotrophic bacteria but represented only a few percent of the retrieved values of $b_{\text {bp-sat }}(440)$. The origin of this difference is mostly a consequence of bubbles and submicrometer particles [Koike et al., 1990] that were not enumerated by the flow cytometer and typically account for 70 to $90 \%$ of the particulate backscattering effect [Stramski and Kiefer, 1991]. The major source of particulate backscattering has been identified as small and numerically abundant nonliving particles [Stramski and Kiefer, 1991; Morel and Ahn, 1990; Stramski et al., 2001]. This is consistent with in situ observations made by Koike et al. [1990] who showed that more than $95 \%$ of the particles counted within the size range $(0.38-1 \mu \mathrm{m})$ were nonliving. According to Stramski and Kiefer [1991], viruses can also be an important source for $b_{\mathrm{bp}}$, but only at "extremely high abundance, for example, $10^{14}$ virions $\mathrm{m}^{-3}$ ". Such concentrations have not been measured in the equatorial Pacific [Fuhrman, 2000]. Bubbles may also contribute to $b_{\mathrm{bp}}$, particularly under high sea states [Stramski and Tegowski, 2001], which was not the case during the time period considered.

[28] This study demonstrates that in case I waters, marine reflectance is governed by extremely small particles, and that nonliving detritus or minerals are a large component of backscattering, but only a small component of the absorption. Since absorption signals in these waters are almost entirely determined by the summed contributions of different groups of living cells, the availability of multichannel ocean color satellite sensors and abundant in situ hyperspectral data over the world oceans may lead to a better understanding of distributional patterns in microbial community composition.

[29] Acknowledgments. We thank Robert Le Borgne as chief scientist of the EBENE cruise on the R/V L'Atalante and our technician Alain Lapetite for laboratory measurements. The authors also thank Hervé Claustre, Jian Wang and collaborators, and one anonymous reviewer who helped to improve the final version of the manuscript. This work was supported by INSU and IRD (UMR 7617).

\section{References}

Ahn, Y. H., A. Bricaud, and A. Morel, Light backscattering efficiency and related properties of some phytoplankters, Deep Sea Res., Part I, 39, $1835-1855,1992$.

Allali, K., A. Bricaud, and H. Claustre, Spatial variations in the chlorophyll-specific absorptions of phytoplankton and photosynthetically active pigments in the equatorial Pacific, J. Geophys. Res., 102, 12,41212,423, 1997.

Behrenfeld, M. J., et al., Biospheric primary production during an ENSO transition, Science, 291, 2594-2597, 2001.

Blanchot, J., J. M. Andre, C. Navarette, J. Neveux, and M. H. Radenac, Picophytoplankton in the equatorial Pacific: Vertical distributions in the warm pool and in the high nutrient low chlorophyll conditions, Deep Sea Res., Part I, 48, 297-314, 2001.

Bricaud, A., A. L. Bedhomme, and A. Morel, Optical properties of diverse phytoplanktonic species: Experimental results and theoretical interpretation, J. Plankton. Res., 10, 851-873, 1988.

Bricaud, A., M. Babin, A. Morel, and H. Claustre, Variability of the chlorophyll-specific absorption coefficients of natural phytoplankton: Analysis and parameterization, J. Geophys. Res., 100, 13,321-13,332, 1995.

Bricaud, A., A. Morel, M. Babin, K. Allali, and H. Claustre, Variations in light absorption by suspended particles with chlorophyll $a$ concentration in oceanic (case 1) waters: Analysis and implications for bio-optical models, J. Geophys. Res., 103, 31,033-31,044, 1998.

Bricaud, A., K. Allali, A. Morel, D. Marie, M. Veldhuis, F. Partensky, and D. Vaulot, Divinyl chlorophyll $a$-specific absorption coefficients and absorption efficiency factors for Prochlorococcus marinus: Kinetics of photoacclimation, Mar. Ecol. Prog Ser, 188, 21-32, 1999.

Bricaud, A., C. Roesler, J. Parslow, and J. Ishisaka, Bio-optical studies during the JGOFS-equatorial Pacific program: A contribution to the knowledge of the equatorial system, Deep Sea Res., Part II, 49, $2583-$ 2600, 2002.

Brown, S. L., M. R. Landry, S. Christensen, D. Garrison, M. M. Gowing, R. R. Bidigare, and L. Campbell, Microbial community dynamics and taxon-specific phytoplankton production in the Arabian Sea during the 1995 monsoon seasons, Deep Sea Res., Part II, 49, 2345-2376, 2002.

Brown, S. L., M. R. Landry, J. Neveux, and C. Dupouy, Microbial community abundance and biomass along a $180^{\circ}$ transect in the equatorial Pacific during an El Niño-Southern Oscillation cold phase, J. Geophys. Res., 108(C12), 8139, doi:10.1029/2001JC000817, in press, 2003.

Chung, S. P., I. D. Walsh, M. J. Richarson, and W. D. Gardner, Beam attenuation and miccroorganisms: Spatial and temporal variations in small particles along $140^{\circ} \mathrm{W}$ during the 1992 JGOFS-EqPac transects, Deep Sea Res., Part II, 43, 1205-1226, 1996.

Chung, S. P., W. D. Gardner, M. R. Landry, M. J. Richardson, and I. S. Walsh, Beam attenuation by microorganisms and detrital particles in the equatorial Pacific, J. Geophys. Res., 103, 12,669-12,681, 1998.

Claustre, H., A. Morel, M. Babin, C. Caillau, D. Marie, J. C. Marty, D. Tailliez, and D. Vaulot, Variability in particle attenuation and chlorophyll fluorescence in the tropical Pacific: Scales, patterns and biogeochemical implications, J. Geophys. Res., 104, 3401-3422, 1999.

Claustre, H., F. Fell, K. Oubelkheir, L. Prieur, A. Sciandra, B. Gentili, and M. Babin, Continous monitoring of surface optical properties across a geostrophic front: Biogeochemical inferences, Limnol. Oceanogr., 45, 309-321, 2000

Deschamps, P. Y., F. M. Breon, M. Leroy, A. Podaire, A. Bricaud, J. C. Buriez, and G. Seze, The POLDER mission: Instrument characteristics and scientific objectives, IEEE Trans. Geosci. Remote Sens., 32, 593615,1994

Dupouy, C., H. Oiry, A. Le Bouteiller, and M. Rodier, Variability of the equatorial phytoplankton enrichment in the western and central Pacific Ocean, in Satellite Remote Sensing of the Ocean, edited by I. S. F. Jones, Y. Sugimori, and R. W. Stewart, pp. 406-419, Seibutsu Kenkyusha, Tokyo, 1993.

Dupouy, C., J. Neveux, and J. M. André, Spectral absorption coefficient of photosynthetically active pigments in the equatorial Pacific $\left(165^{\circ} \mathrm{E}-\right.$ $\left.150^{\circ} \mathrm{W}\right)$, Deep Sea Res., Part II, 44, 1881-1906, 1997. 
DuRand, M. D., and R. J. Olson, Contributions of phytoplankton light scattering and cell concentration changes to diel variations in beam attenuation in the equatorial Pacific from flow cytometry measurements of pico-, ultra- and nanophytoplankton, Deep Sea Res., Part II, 42, 891 906, 1996.

DuRand, M. D., and R. J. Olson, Diel patterns in optical properties of the chlorophyte Nannochloris sp.: Relating individual-cell to bulk measurements, Limnol. Oceanogr., 43, 1107-1118, 1998.

DuRand, M. D., R. E. Green, H. M. Sosik, and R. J. Olson, Diel variations in optical properties of Micromonas pusilla (Prasinophyceae), J. Phycol., $38,1132-1142,2002$.

Dusenberry, J. A., R. J. Olson, and S. W. Chisholm, Photoacclimation kinetics of single cell fluorescence in laboratory and field populations of Prochlorococcus, Deep Sea Res., Part I, 48, 1443-1458, 2001.

Eppley, R. W., F. M. H. Reid, and J. D. H. Strickland, Estimates of phytoplankton crop size, growth rate, and primary production, in The Ecology of Phytoplankton off La Jolla California in the Period April Through September, 1967, edited by J. D. H. Strickland, Bull. Scripps Inst. Oceanogr, 17, 33-42, 1970.

Finkel, Z. V., Light absorption and size scaling of light-limited metabolism in marine diatoms, Limnol. Oceanogr., 46, 86-94, 2001.

Frouin, R., P. Y. Deschamps, B. G. Mitchell, and M. Kahru, The normalized difference phytoplankton index for satellite ocean color application, EOS Trans. $A G U, 79,1,161,1998$.

Fuhrman, J. A., Impact of viruses on planktonic bacteria, in Microbial Ecology of the Oceans, edited by D. L. Kirchman, pp. 327-350, John Wiley, Hoboken, N. J., 2000.

Gordon, H. R., and A. Morel, Remote Assessment of Ocean Color for Interpretation of Visible Imagery: A Review, 114 pp., Springer-Verlag, New York, 1983

Gordon, H. R., O. B. Brown, R. H. Evans, J. W. Brown, R. S. Smith, K. S. Baker, and D. K. Clark, A semi-analytic radiance model of ocean color, J. Geophys. Res., 93, 10,909-10,924, 1988.

Johnsen, G., N. Nelson, R. V. M. Jovine, and B. Prezelin, Chromoproteinand pigment-dependent modeling of spectral light absorption by two dinoflagellates, Prorocentrum minimum and Heterocapsa pygmaea, Mar. Ecol. Prog. Ser., 114, 245-258, 1994.

Kishino, M., M. Takahashi, N. Okami, and S. Ichimura, Estimation of the spectral absorption coefficients by phytoplankton in the sea, Bull. Mar. Sci., 37, 634-642, 1985.

Koike, I., S. Hara, K. Terauchi, and K. Kogure, Role of sub-micrometre particles in the ocean, Nature, 345, 242-244, 1990.

Le Borgne, R., and M. R. Landry, EBENE: A JGOFS investigation of plankton variability and trophic interactions in the equatorial Pacific $\left(180^{\circ}\right)$, J. Geophys. Res., 108(C12), 8136, doi:10.1029/2001JC001252, in press, 2003.

Lee, Z., K. L. Carder, R. G. Steward, T. G. Peacock, C. O. Davis, and J. S. Patch, Empirical ocean color algorithms for absorption coefficients of optically deep waters, J. Geophys. Res., 103, 27,967-27,978, 1998.

Lindley, S. T., R. R. Bidigare, and R. T. Barber, Phytoplankton photosynthesis parameters along $140^{\circ} \mathrm{W}$ in the equatorial Pacific, Deep Sea Res., Part II, 42, 441-463, 1995.

Loisel, H., and A. Morel, Light scattering and chlorophyll concentration in case I waters: A re-examination, Limnol. Oceanogr., 43, 847-858, 1998.

Loisel, H., and D. Stramski, Estimation of the inherent optical properties of natural waters from the irradiance attenuation coefficient and reflectance in the presence of Raman scattering, Appl. Opt., 39, 3001-3011, 2000.

Loisel, H., D. Stramski, B. G. Mitchell, F. Fell, V. Fournier-Sicre, B. Lemasle, and M. Babin, Comparison of the ocean inherent optical properties obtained from measurements and inverse modeling, Appl. Opt., 40, 2384-2397, 2001.

Maffione, R. A., and D. R. Dana, Instrument for measuring the backward scattering coefficient of ocean waters, Appl. Opt., 36, 6057-6067, 1997.

Marra, J., C. Trees, R. R. Bidigare, and R. T. Barber, Pigment absorption and quantum yields in the Arabian Sea, Deep Sea Res., Part II, 47, 1279-1299, 1999.

McClain, C., J. R. Christian, S. R. Signorini, M. R. Lewis, I. Asanuma, D. Turk, and C. Dupouy, Satellite ocean color observations of the Pacific Ocean, Deep Sea Res., Part II, 49, 2533-2560, 2002.

Mitchell, B. G., Algorithms for determining the absorption coefficient of aquatic particulates using the quantitative filter technique (QFT), Proc. SPIE Int. Soc. Opt. Eng., 1302, 137-148, 1990.

Mobley, C., and D. Stramski, Effects of microbial particles on oceanic optics: Methodology for radiative transfer modelling and example simulations, Limnol. Oceanogr., 42, 550-560, 1997.

Moore, L. R., R. Goericke, and S. W. Chisholm, Comparative physiology of Synechococcus and Prochlorococcus influence of light and temperature on growth pigments, fluorescence and absorptive properties, Mar. Ecol. Prog. Ser., 116, 259-275, 1995.
Morel, A., Chlorophyll-specific scattering coefficient of phytoplankton. A simplified theoretical approach, Deep Sea Res., Part A, 34, 1093-1105, 1987.

Morel, A., Optical modeling of the upper ocean in relation to its biogenous matter content (case I waters), J. Geophys. Res., 93, 10,749-10,768, 1988.

Morel, A., Optics of marine particles and marine optics, in Particle Analysis in Oceanography, edited by S. Demers, pp. 141-187, Springer-Verlag, New York, 1991.

Morel, A., Consequences of a Synechococcus bloom upon the optical properties of oceanic (case 1) waters, Limnol. Oceanogr., 42, 1746-1754, 1997.

Morel, A., and Y. H. Ahn, Optical efficiency factors of free living bacteria: Influence of bacterioplankton upon the optical properties and particulate organic carbon in oceanic waters, J. Mar. Res., 48, $145-175,1990$

Morel, A., and Y. H. Ahn, Optics of heterotrophic nanoflagellates and ciliates: A tentative assessment of their backscattering role in oceanic waters compared to those of bacterial and algal cells, J. Mar. Res., 49, 177-202, 1991 .

Morel, A., and A. Bricaud, Theoretical results concerning absorption in a discrete medium, and application to the specific absorption coefficient of phytoplankton, Deep Sea Res, Part I, 28, 13751393, 1981.

Morel, A., and S. Maritorena, Bio-optical properties of oceanic waters: A reappraisal, J. Geophys. Res., 106, 7163-7180, 2001.

Morel, A., Y. H. Ahn, F. Partensky, D. Vaulot, and H. Claustre, Prochlorococcus and Synechococcus: A comparative study of their optical properties in relation to their size and pigmentation, J. Mar. Res., 51, 617649,1993

Murakami, H., J. Ishizaka, and H. Kawamura, ADEOS observations of chlorophyll a concentration, sea surface temperature, and wind stress change in the equatorial Pacific during the 1997 El Nino onset, J. Geophys. Res., 105, 19,551-19,559, 2000.

Neveux, J., and F. Lantoine, Spectrofluorometric assay of chlorophylls and phaeopigments using the least squares approximation technique, Deep Sea Res., Part I, 40, 1747-1765, 1993.

Neveux, J., C. Dupouy, J. Blanchot, A. Le Bouteiller, M. R. Landry, and S. L. Brown, Diel dynamics of chlorophylls in high-nutrient, low-chlorophyll waters of the equatorial Pacific $\left(180^{\circ}\right)$ : Interactions of growth, grazing, physiological responses, and mixing, J. Geophys. Res., 108(C12), 8140, doi:10.1029/2000JC000747, in press, 2003.

O'Reilly, J. E., S. Maritorena, B. G. Mitchell, D. A. Siegel, K. L. Carder, S. A. Garver, M. Kahru, and C. McCLain, Ocean color chlorophyll algorithm for SeaWiFS, J. Geophys. Res., 103, 24,93724,953, 1998.

Pope, R. M., and E. S. Fry, Absorption spectrum $(380-700 \mathrm{~nm})$ of pure water: II, Integrating cavity measurements, Appl. Opt., 36, 8710-8723, 1997.

Radenac, M. H., C. Menkes, J. Vialard, C. Moulin, Y. Dandonneau, T. Delcroix, C. Dupouy, A. Stoens, and P.-Y. Deschamps, Modeled and observed impacts of the 1997-1998 El Niño on nitrate and new production in the equatorial Pacific, J. Geophys. Res., 106, 26,879-26,898, 2001.

Roesler, C., and M. J. Perry, In situ phytoplankton absorption, fluorescence emission, and particulate backscattering spectra determined from reflectance, J. Geophys. Res., 100, 13,279-13,294, 1995.

Simeon, J., C. Roesler, S. Pegau, and C. Dupouy, Sources of spatial variability in light absorbing components along an equatorial transect from $165^{\circ} \mathrm{E}$ to $15^{\circ} \mathrm{W}, \mathrm{J}$. Geophys. Res., 108, doi:10.1029/2002JC001613, in press, 2003.

Smith, R. C., and K. Baker, Optical properties of the clearest natural waters, Appl. Opt., 20, 177-184, 1981.

Sosik, H., and B. G. Mitchell, Absorption, fluorescence, and quantum yield for growth in nitrogen-limited Dunaliella tertiolecta, Limnol. Oceanogr., 36, 910-921, 1991.

Stramski, D., and D. Kiefer, Light scattering by microorganisms in the upper ocean, Prog. Oceanogr, 28, 321-345, 1991.

Stramski, D., and D. A. Kiefer, Can heterotrophic bacteria be important to marine light absorption?, J. Plankon Res., 20, 1489-1500, 1998.

Stramski, D., and C. D. Mobley, Effects of microbial particles on oceanic optics: A database of single-particle optical properties, Limnol. Oceanogr., 42, 538-549, 1997.

Stramski, D., and R. Reynolds, Diel variations in the optical properties of a marine diatom, Limnol. Oceanogr., 38, 1347-1364, 1993.

Stramski, D., and J. Tegowski, Effects of intermittent entrainment of air bubbles by breaking wind waves on ocean reflectance and underwater light field, J. Geophys. Res., 106, 31,345-31,360, 2001. 
Stramski, D., R. Reynolds, M. Kahru, and B. G. Mitchell, Estimation of particulate organic carbon in the ocean from satellite remote sensing, Science, 285, 239-242, 1999.

Stramski, D., A. Bricaud, and A. Morel, Modeling the inherent optical properties of the ocean based on the detailed composition of the planktonic community, Appl. Opt., 40, 2929-2945, 2001.

Strathmann, R. E., Estimating the organic carbon content of phytoplankton from cell volume or plasma volume, Limnol. Oceanogr., 36, 50-63, 1967.

J. Blanchot, Institut de Recherche pour le Développement (IRD)-Sainte Clotilde, St. Clotilde, 97940 La Réunion, France.
S. L. Brown and M. R. Landry, Department of Oceanography, University of Hawaii at Manoa, 1000 Pope Rd., Honolulu, HI, 96822, USA.

C. Dupouy, LODYC (CNRS-IRD-UPMC), UMR 7617, UPMC, 4 Place Jussieu, 75452 Paris, France. (cdu@lodyc.jussieu.fr)

A. Le Bouteiller, IRD-Nouméa, BP A5, Nouméa, 98848 Nouvelle, Calédonie.

H. Loisel, Université du Littoral Côte d'Opale, MREN-UMR 8013 ELICO-LOCL, 32 Avenue Foch, 62930 Wimereux, France.

C. Moulin, Laboratoire des Sciences du Climat et de 1'Environnement, CEA-CNRS, 91191 Gif-sur-Yvette, France.

J. Neveux, Observatoire Océanologique de Banyuls (CNRS-UPMC), Laboratoire Arago (UMR 7621), BP44, 66651 Banyuls sur Mer, France. 